\title{
Graptolite assemblages and stratigraphy of the lower Silurian Mrákotín Formation, Hlinsko Zone, NE interior of the Bohemian Massif (Czech Republic)
}

\author{
PETR ŠTORCH \& PETR KRAFT
}

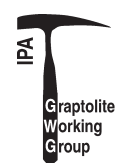

\begin{abstract}
Most of the graptolite biozones, previously recognized in the Llandovery succession of the classical Barrandian area of central Bohemia, are here identified in the heavily tectonized and poorly exposed, epizonal and contact metamorphic black slates and silicites of the Mrákotín Formation of the Hlinsko Zone. Graptolite material was collected by bulk sampling of loose boulders. The lower Llandovery (Rhuddanian) Cystograptus vesiculosus and Coronograptus cyphus biozones, Demirastrites triangulatus, D. pectinatus, "Monograptus" simulans, Pribylograptus leptotheca, Lituigraptus convolutus and Stimulograptus sedgwickii biozones of middle Llandovery (Aeronian) age and Rastrites linnaei, Spirograptus turriculatus, Streptograptus crispus and Monoclimacis griestoniensis biozones of late Llandovery (Telychian) age were identified in those loose boulders. The upper Telychian Torquigraptus tullbergi and Oktavites spiralis biozones were found in outcrop. The sedimentary succession of the Mrákotín Formation has been reconstructed, in particular by detailed correlation with the biostratigraphically well dated, graptolite-rich successions in the Barrandian area, Thuringia and elsewhere. 112 graptolite species are recorded; selected graptolites are figured and briefly discussed; Pseudorthograptus finneyi sp. nov. is described. There is little difference between the graptolite faunas of the Hlinsko Zone and the Barrandian area, but the lithological successions of the two areas differ. In the Hlinsko Zone the entire Llandovery is developed as anoxic black slates, siliceous slates and silicites. The black siliceous slates and silicites exhibit light coloured, quartz/chalcedony nodules such as characterize the basinal Silurian black shales and silicites in Thuringia and Sardinia. Barren greenish mudstone beds, which intercalate with the black graptolitic shales of the upper Llandovery Litohlavy Formation in the Barrandian area, are missing in the Hlinsko Zone. We assume that the Mrákotín Formation of the Hlinsko Zone was deposited near the depositional site of the coeval formations of Saxo-Thuringia and West Sudetes, rather than near the Barrandian area. - Key words: graptolites, stratigraphy, Llandovery, Hlinsko Zone, Bohemian Massif.
\end{abstract}

ŠTORCH, P. \& KRAFT, P. 2009. Graptolite assemblages and stratigraphy of the lower Silurian Mrákotín Formation, Hlinsko Zone, NE interior of the Bohemian Massif (Czech Republic). Bulletin of Geosciences 84(1), 51-74 (13 figures, 2 tables). Czech Geological Survey, Prague. ISSN 1214-1119. Manuscript received January 5, 2008; accepted in revised form April 30, 2008; published online December 3, 2008; issued March 31, 2009.

Petr Štorch, Academy of Sciences of the Czech Republic, Institute of Geology, Rozvojová 135, 16502 Praha 6, Czech Republic; storch@gli.cas.cz•Petr Kraft, Charles University, Faculty of Science, Institute of Geology and Palaeontology, Albertov 6, 12843 Praha 2, Czech Republic; kraft@natur.cuni.cz.

The Hlinsko Zone is a small, low-grade metamorphosed, tectonically bounded regional geologic unit in the north-eastern interior of the Bohemian Massif (Fig. 1). It represents southeastern extension of Lugicum Variscan Zone (Cháb et al. 2008) nested between the northeastern periphery of the Bohemicum Variscan Unit and northwestern margin of the Moldanubicum Variscan Unit. The metasedimentary units of the Hlinsko Zone are bounded by the Železné hory Plutonic Complex to the west and the high-grade metamorphosed Svratka Crystalline unit of the Moldanubicum to the east (Pitra et al. 1994). There are two lithostratigraphic units distinguished within the Hlinsko Zone unit: The Hlinsko-Rychmburk Formation and the
Mrákotín Formation. Only the heavily tectonized and poorly exposed, epizonal and contact metamorphic black siliceous slates and silicites of the Mrákotín Formation have yielded identifiable fossils - almost exclusively graptolites (Horný 1956, Chlupáč et al. 2002).

Graptolite bearing graphitic slates and silicites are commonly the only rocks in epizonal- and contact-metamorphosed European Variscan formations that can be biostratigraphically dated by macrofossils. The rich graptolite faunas encountered in the Mrákotín Formation of the Hlinsko Zone enable reliable and precise dating of the rocks. Reconstruction of the original sedimentary successsion may shed, to some degree, light on the 


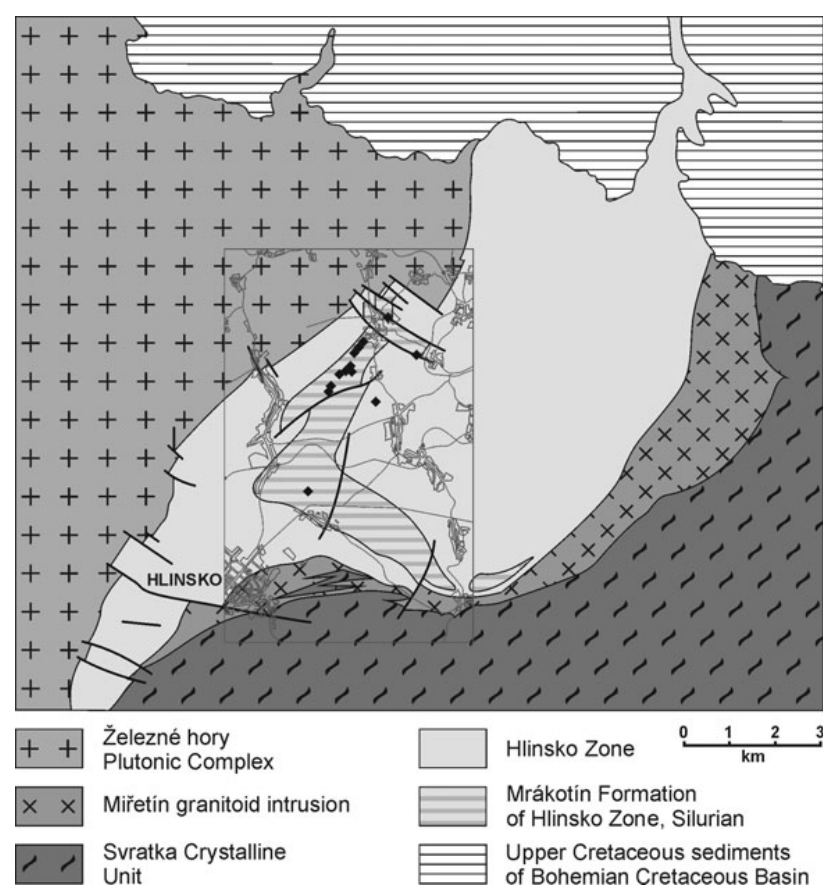

Figure 1. Geological sketch-map of the Hlinsko Zone unit (based on official Geological Map of Czechoslovakia, $1: 200$ 000, issued by the Czech Geological Survey, 1964). The semi-transparent topographical map in the centre of the figure is identical to the Fig. 2, except for simplification. Localities are marked by rhomboids.

palaeogeographic links of the Hlinsko Zone with the other Lower Palaeozoic units of the Bohemian Massif.

\section{History of palaeontological and stratigraphical research}

The first fossils discovered in the Hlinsko Zone were graptolites found iby A. Wurm, a teacher from nearby town of Chotěboř, in 1920's. Wurm (1927) published a short report on rare and poorly preserved monograptids from Modrá skála near Hlinsko, Medkovy kopce, and from the vicinity of the road from Hlinsko to Polička. The richest fossil site he noted was that near Mrákotín (locality "Za humny", locality 2). In addition to undeterminable monograptids with straight rhabdosomes, A. Wurm reported Monograptus (= Oktavites) spiralis (Geinitz) and thus gave undoubted evidence for the Silurian age of black silicites in the central part of the Hlinsko Unit. Wurm (1927) suggested close similarity of the lyditedominated Silurian of Hlinsko area to Silurian succession in Saxony and West Sudetes.

For the next thirty years this area was out of the palaeontological focus. New interests appeared in connection with the general geological mapping of Czechoslovakia in 1950s. At that time extensive palaeontological and stratigraphical research was carried out. Horný (1956) pub- lished a comprehensive stratigraphic report, including preliminary graptolite data. He recognized four lower Silurian graptolite biozones [Demirastrites pectinatus, Demirastrites (now Lituigraptus) convolutus, Globosograptus (now Streptograptus) crispus, and Spirograptus (now Oktavites) spiralis, see Table 1], listed 28 taxa and provided several illustrations. Since the 1950 s no systematic palaeontological research has been conducted on the Silurian of the Hlinsko Zone. Unfortunatelly, the exact location of several fossil sites and other details, such as fossil bearing lithotypes, have been forgotten after almost fifty years. In this respect, our research can be considered as a re-discovery of the localities and methods of how to find and collect graptolites in this region.

No significant micropalaeontological research has yet been undertaken in the Hlinsko Zone. Konzalová \& Vachtl (1976) reported acritarchs from thin sections of Silurian silicites from Oflenda, Raná, Dolní Holetín, Vojtěchov and Kladno. Those microfossils, however, were not determined, illustrated or described in detail as the study focused on a comparison of the organic matter alteration and degree of degradation in different rocks of the Hlinsko Zone.

\section{Localities}

The graptolite-bearing Silurian black slates and silicites are confined to a narrow belt. Its northern part is oriented NNE-SSW and its southern part curves to the south-east (Fig. 1). The hard siliceous rocks form a low, flat, partly forested range in the northern part while the southern part does not have such a distinctly elevated upland landscape.

The uncommon and usually small natural exposures of Silurian rocks are concentrated especially in the northern part of the area. A few artificial exposures, such as small quarries, temporary excavations and one road cut, complete the list of these sporadic exposures over the whole area. A very high proportion of the Silurian basement is covered by Quaternary geest and soil. However, the hardness of the Silurian rocks, especially of the silicites, causes them to resist weathering and denudation, and has led to the common occurrence of loose stones and boulders, displaced by gravity and partly also by farming activities. They are dispersed widely around the primary source area. Although the slopes along the range and elevations are in general gentle, loose stones and boulders have been displaced in considerable distances.

The bedding of the hard Silurian silicites, enhanced by tectonic effects on the interlayers, has allowed natural disintegration into flat blocks utilized sometimes as building stones by local dwellers. The stones were often in the past gathered and removed from fields to small dumps at the margins, to balks and to small forests or were used for 
the reinforcing of local roads. Such concentrations proved ideal places for fossil collection because the area of provenance of the blocks can be easily estimated as from nearby. However, this is only a secondary provenance, as the blocks had been moved before anyway.

Graptolites have been recorded from several places along the major part of the Silurian belt. The principal material was collected by R. Horný, J. Kř́ž and the present authors. Horný (1956) mentioned material from the following localities and stratigraphic levels (according to the original designation): Mrákotín (Demirastrites pectinatus, Demirastrites convolutus, Globosograptus crispus and Spirograptus spiralis biozones), Oflenda (Dem. convolutus Biozone and S. spiralis = Spirograptus turriculatus Biozone in present usage), Medkovy kopce (Dem. pectinatus and Dem. convolutus biozones), Vojtěchov (Dem. pectinatus and Dem. convolutus biozones) and Kladno (Dem. convolutus Biozone). He also mentioned the locality Malinné but without any list of fossils. In addition, he referred to Malinné, Mrákotín (Za humny), Medkovy kopce and Kladno (V dolích) as exposures. As Horný (1956) did not describe the exact positions of the localities, we tried to verify and rediscover them during our field research:

Mrákotín. - This name encompasses several sites. It is probable that Horný used the name Mrákotín for loose stones and boulders. The specified location Mrákotín (Za humny) was most likely used for exposures at a small quarry, which we call Picek's Quarry (see below; Fig. 2, locality 2a), and its surroundings.

Oflenda. - It is not clear where the dividing line between the localities of Mrákotín and Oflenda was considered to be by Horný. Both villages are situated close to each other and the main graptolite occurrence area is equidistant from them. We have documented only one natural exposure near Oflenda. There is a tectonically affected slate and silicite succession in the slope above the Mrákotínský potok Brook, some $150 \mathrm{~m} \mathrm{NW}$ of the settlement margin $\left(49^{\circ}\right.$ $\left.48^{\prime} 32.4^{\prime \prime} \mathrm{N}, 15^{\circ} 57^{\prime} 16.5^{\prime \prime} \mathrm{E}\right)$. We have found no fossils there. Most probably, this outcrop and its surroundings on the right bank of the brook do not correspond to Horný's locality. We suppose that loose stones from the field on the slope between the crest of the Silurian rock range and the left side of the Mrákotínský potok Brook gorge, west of Oflenda, represent the locality.

Medkovy kopce. - We found graptolites in loose stones (see below), but no exposure.

Vojtěchov. - We didn't find fossils in the vicinity of Vojtěchov. According to Horný (pers. comm.), he collected loose stones in the fields west (or south-west) of the village.
Kladno. - It is apparent that collection was made in a road-cut on the former curve (and possibly also in its surroundings) of the Hlinsko-Polička road, some $750 \mathrm{~m}$ west of Kladno ( $49^{\circ} 46^{\prime} 39.4^{\prime \prime} \mathrm{N}, 15^{\circ} 58^{\prime} 14.6^{\prime \prime} \mathrm{E}$; Fig. 2, locality $\mathrm{Kl}$ ). After the straightening of the road the curve was abandoned but in its western part a low exposure of silicites has been preserved. We tried to collect there but didn't find any fossils.

The upper part of the exposed succession is highly silicifed while the lower portion less so. Our assumption, confirmed by J. Kříž (pers. comm.), is that graptolites came from the lower portion, which is partly dug out, overhung and covered. Křiž named this locality and labelled his graptolite material as Krouna after the nearest village directly on the main Hlinsko-Polička road.

Malinné. - No exposures or loose stones were found around the settlement which sits on a granitoid elevation. We examined the area along the road from Malinné to Mrákotín but without any positive result.

\section{Mrákotín}

(1) The first graptolites that we rediscovered in the Hlinsko Zone (in 1999) were in dumps of stones taken from fields around Mrákotín and stored in a farm yard of Agricultural Cooperative Mrákotín (around the point $49^{\circ} 49^{\prime} 03.5^{\prime \prime} \mathrm{N}$, $15^{\circ} 57^{\prime} 38.5^{\prime \prime}$ E; Fig. 2, locality 1). The big dumps yielded many graptolite-bearing blocks of Silurian slates and silicites with assemblages of the Coronograptus cyphus to Lituigraptus convolutus biozones. Although the exact original locations of these rocks are unknown, this is not a critical problem given that they were loose stones in the first place. The cumulative assignment to the locality Mrákotín is used. The dumps have been covered and no longer exist.

The richest localities are concentrated around ground elevation land-mark 530.3, situated $1 \mathrm{~km} \mathrm{SW}$ of Mrákotín (49 $\left.48^{\prime} 22.9^{\prime \prime} \mathrm{N}, 15^{\circ} 56^{\prime} 50.7^{\prime \prime} \mathrm{E}\right)$. For this reason we focused our attention especially on this area (Fig. 2, localities 2-4). We proved most Llandovery graptolite biozones (between Cystograptus vesiculosus and Oktavites spiralis).

(2) Mrákotín - south-west of GMS tower ("Za humny"; Fig. 2, locality 2). A small area 200-300 m SW of the GMS tower, which is situated $180 \mathrm{~m} \mathrm{SW}$ of the ground elevation land-mark 530.3. Two important sites were recorded:

(2a) Mrákotín - Picek's Quarry (Fig. 2, locality 2a). A small, shallow, abandoned quarry, partly filled with waste in a grove some $1.5 \mathrm{~km} \mathrm{SW}$ of Mrákotín. A several metres thick succession of slates and silicites is exposed in its north-western part. We discovered graptolites in the middle of the succession in the quarry (Torquigraptus tullbergi 
Table 1. Stratigraphic levels of the Mrákotín Formation documented by graptolite data. The zonal chart in the left-hand column after Storch (1994) updated by Storch (2006). Frequency of finds from the respective zones is marked: - zone not found; + rare to sporadic occurrence; ++ infrequent; +++ common; $\bullet$,in situ “ recorded zone. Frequencies in the right column estimated after description provided by Horný (1956).

\begin{tabular}{|c|c|c|c|c|}
\hline Series & Stages & Graptolite Zone & Horný (1956) & $\begin{array}{l}\text { Storch \& Kraft } \\
\text { (this paper) }\end{array}$ \\
\hline \multirow{18}{*}{$\begin{array}{l}\overrightarrow{0} \\
0 \\
0 \\
0 \\
0 \\
\text { 吾 } \\
\end{array}$} & \multirow{8}{*}{ 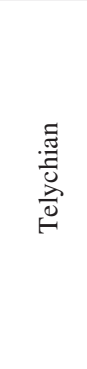 } & insectus & - & - \\
\hline & & lapworthi & & - \\
\hline & & spiralis & ++ & $\cdot$ \\
\hline & & tullbergi & - & - \\
\hline & & griestoniensis & - & ++ \\
\hline & & crispus & + & ++ \\
\hline & & turriculatus & - & +++ \\
\hline & & linnaei & - & ++ \\
\hline & \multirow{6}{*}{ 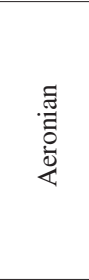 } & sedgwickii & - & + \\
\hline & & convolutus & +++ & ++ \\
\hline & & leptotheca & - & +++ \\
\hline & & simulans & & + \\
\hline & & pectinatus & ++ & ++ \\
\hline & & triangulatus & - & +++ \\
\hline & \multirow{4}{*}{ 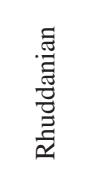 } & cyphus & - & ++ \\
\hline & & vesiculosus & - & + \\
\hline & & acuminatus & - & - \\
\hline & & ascensus & - & - \\
\hline
\end{tabular}

Note: At the time of Horný's (1956) paper, the leptotheca Zone was not in use, the simulans Zone corresponded to the pribyli Zone, the tullbergi Zone to the crenulata Zone, and the major part of the lapworthi Zone to the grandis Zone.

Biozone; spot $1,49^{\circ} 48^{\prime} 09.5^{\prime \prime} \mathrm{N}, 15^{\circ} 56^{\prime} 35.0^{\prime \prime} \mathrm{E}$ ) and near the top of the succession just behind the edge of the quarry wall in the NW corner of the quarry ( $\operatorname{spot} 2,49^{\circ} 48^{\prime} 09.8^{\prime \prime} \mathrm{N}$, $\left.15^{\circ} 56^{\prime} 35.3^{\prime \prime} \mathrm{E}\right)$. Several levels with bedding planes covered with poorly preserved graptolites were recorded in the latter spot in a several tens of centimetres thick succession of slates (Oktavites spiralis Biozone). Straight stipes of robust monograptids are most common; several specimens of Oktavites spiralis were also recorded. Picek's Quarry is the only locality where we found graptolites in situ.

Picek's Quarry is the local name of this site. In old map from the $19^{\text {th }}$ century $\left(3^{\text {rd }}\right.$ Military Survey; $1: 25$ 000; map sheet 4056/3) the area around is called Za humny. This designation was used by Wurm (1927) for his main graptolite locality. As the character of graptolite assemblage, including "Monograptus spiralis", corresponds with its description, it is clear that this is the key place from where Silurian graptolites were proved for the first time in the definite Hlinsko area.

(2b) Mrákotín - field margin along the NW edge of the small forest SW of the GMS tower (around the point $49^{\circ} 48^{\prime} 13.4^{\prime \prime} \mathrm{N}, 15^{\circ} 56^{\prime} 40.0^{\prime \prime}$ E; Fig. 2, locality 2b). Sporadic loose stones with graptolites occur in the field close to the small forest.

(3) Mrákotín - N to NE of the ground elevation landmark 530.3 (Fig. 2, locality 3 ). This area, which includes part of the forest and adjacent fields, appears to be the most fossiliferous and yielded the majority of loose stones with graptolites.

(3a) Mrákotín - forest NE of the ground elevation land-mark 530.3 (Fig. 2, locality 3a). The area of forested top of the range is limited by the unpaved road from Mrákotín in the NW and field margin in the SE. The elevation-mark is at its SW limit and the area extends some $160 \mathrm{~m} \mathrm{NE}$ to its NE edge. The loose stones can be found in the forest and on the unpaved road. The best concentrations of graptolite-rich stones are around a short track connecting the marginal road from Mrákotín with the field SE of the forest. That short track runs in a N-S direction, $60 \mathrm{~m}$ from the land-mark (around the point $49^{\circ} 48^{\prime} 24.5^{\prime \prime} \mathrm{N}, 15^{\circ}$ 56 52.6" E; Fig. 2, loc. 3a, ellipse in SW part). Many graptolite-bearing loose stones were excavated from the soil in the forest around the track. Some stones probably used for reinforcing the track in the past were extracted from it. Numerous fossiliferous stones came also from a big dump near the $\mathrm{S}$ end of the track. This spot was probably the richest in diverse graptolites representing Coronograptus cyphus to Monoclimacis griestoniensis biozones. Another important spot is in an area of windthrow in the forest in the NE part of the locality area $\left(49^{\circ} 48^{\prime} 27.1^{\prime \prime} \mathrm{N}\right.$, $15^{\circ} 56^{\prime} 55.8^{\prime \prime}$ E; Fig. 2; loc 3a, NE point). This place yielded some less tectonized and less metamorphosed blocks of slates with extraordinarily well preserved graptolites.

(3b) Mrákotín - small forest. Numerous loose stones accumulated in a small forest by farmers from the field $\mathrm{W}$ of the elevation land-mark 530.3. The most fossiliferous stones were found at its NW and $\mathrm{N}$ edge (surrounding of $49^{\circ} 48^{\prime} 22.5^{\prime \prime} \mathrm{N}, 15^{\circ} 56^{\prime} 44.5^{\prime \prime}$ E; Fig. 2, locality 3b).

(3c) Mrákotín - field NE of the elevation land-mark 530.3. Loose stones with graptolites were collected both from dumps and concentrations at the forest margin some 70 to $170 \mathrm{~m} \mathrm{NE}$ of the land-mark and the adjacent field margin (around the point $49^{\circ} 48^{\prime} 25.0^{\prime \prime} \mathrm{N}, 15^{\circ} 56^{\prime} 54.5^{\prime \prime} \mathrm{E}$; Fig. 2, locality $3 \mathrm{c}$ ). This place probably best corresponds to the locality Oflenda of Horný (1956) (see above).

(4) Mrákotín - area around the unpaved road SW of village. From the numerous loose stones from the surrounding fields, concentrated in small dumps, stones in the road and neighbouring forest, only some yielded sporadic, usually poorly preserved graptolites. The main site in this area was a small dump of stones from the surrounding field $\left(49^{\circ}\right.$ $48^{\prime} 36.7^{\prime \prime} \mathrm{N}, 15^{\circ} 57^{\prime} 02.0^{\prime \prime} \mathrm{E}$; Fig. 2, locality 4, SW point) and a small stone concentration from the field adjacent to the small farm $\left(49^{\circ} 48^{\prime} 46.2^{\prime \prime} \mathrm{N}, 15^{\circ} 57^{\prime} 11.4^{\prime \prime} \mathrm{E}\right.$; Fig. 2, loc. 4, NE point). 
In the Mrákotín area only the places with concentration of loose stones or important discoveries have been listed above. Separate loose stones with graptolites can be found in other locations, additional to those described.

\section{Oflenda}

(5) Oflenda - grove with a small abandoned quarry $\left(49^{\circ}\right.$ $48^{\prime} 10.1^{\prime \prime} \mathrm{N}, 15^{\circ} 57^{\prime} 24.8^{\prime \prime}$ E; Fig. 2, locality 5). Among many blocks of greywackes and sandstones, one block of highly contact metamorphosed black slate was found. It yielded undeterminable graptolites and fragments of flattened cephalopods - the only non-graptolite fossils found.

\section{Oldřetice}

(6) Oldřetice - one boulder in a hole excavated for a fence post of private property $\mathrm{W}$ of the settlement $\left(49^{\circ} 48^{\prime} 32.2^{\prime \prime} \mathrm{N}\right.$, $15^{\circ} 58^{\prime} 14.0^{\prime \prime}$ E; Fig. 2, locality 6). One exceptional block yielded dimorphograptids and Cystograptus vesiculosus. This find represents the sample most distant from its source rock with determinable graptolites. Very far transported fragments of Silurian rocks occur up to western vicinity of Oldřetice. Only undeterminable graptolites have been recorded there.

\section{Medkovy kopce}

(7) Medkovy kopce - low slope of terrain step trending $\mathrm{W}-\mathrm{E}$ in a small forest NNE of the elevation point $638.0 \mathrm{~m}$

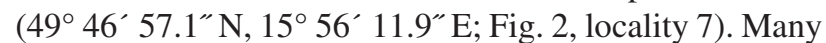
loose stones occur in the soil around the step but only a few contained poorly preserved graptolites. Medkovy kopce represents the southernmost locality from which we have recorded fossils.

Wurm (1927) mentioned "unfavorable preserved monograptids" north of the elevation point at Medkovy kopce (called in that time Modrá skála = Blue rocks). He also found graptolites in two places east of the elevation point. One was apparently $\mathrm{ca} 1 \mathrm{~km} \mathrm{ENE}$, in the small forest, and the other $c a 1.4 \mathrm{~km} \mathrm{E}$ (half way between the Medkovy kopce and Kladno localities), close to the Hlinsko-Polička road in a small quarry which no longer exists. We found no graptolites in that area.

Although we tried to collect in several places where the belt of the Silurian rocks bends to the south-east, we were not successful. Except for Kladno (see above) and perhaps Vojtěchov (the source area of samples is questionable; see above), no fossiliferous localities are known in this area. This may be because the Silurian rocks here in the SE are

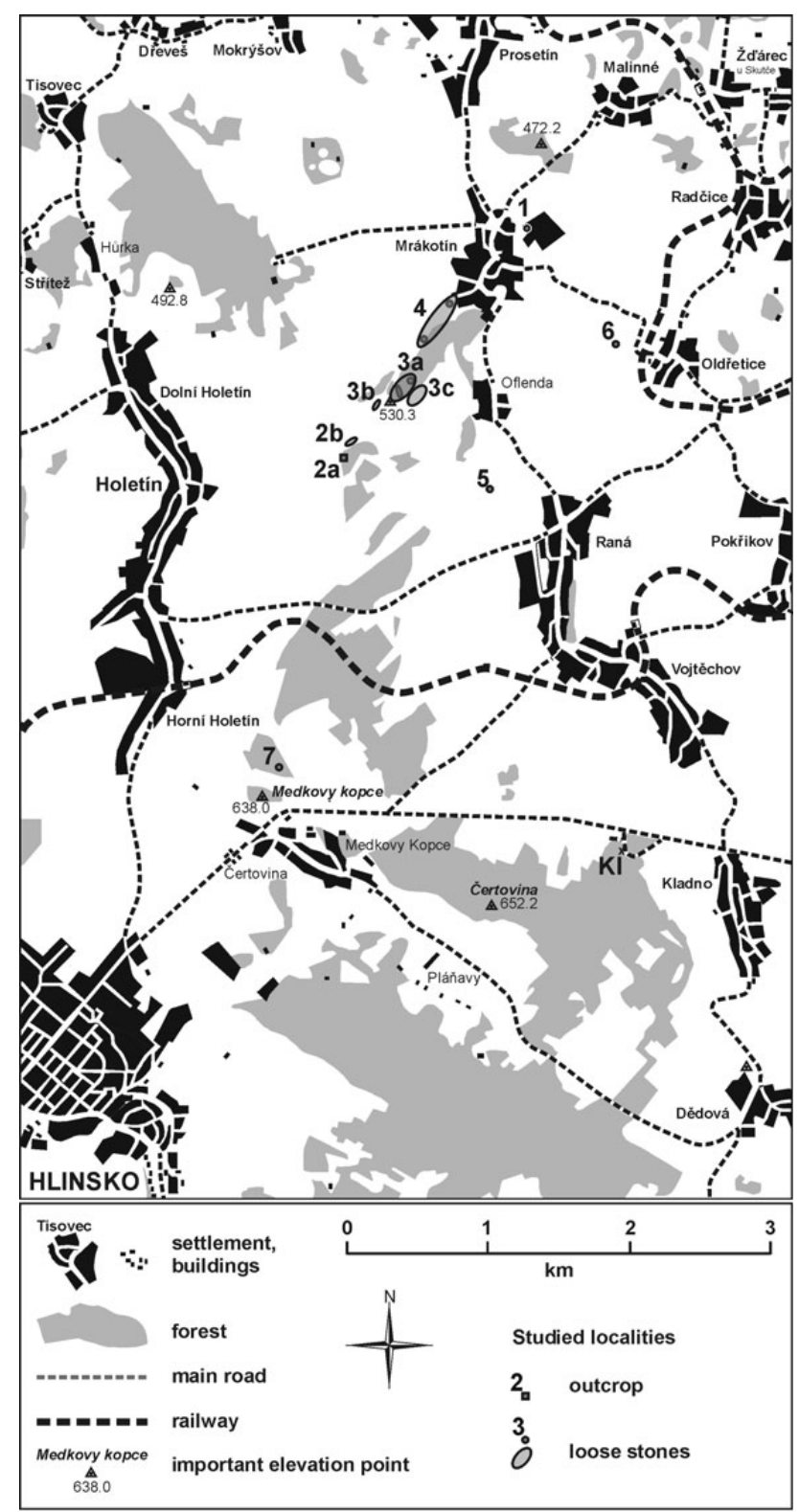

Figure 2. Fossiliferous localities in the Hlinsko Zone investigated in 2000-2004. 1 - Mrákotín - farm yard of Agricultural Cooperative; 2 - Mrákotín - south-west of GMS tower ("Za humny”), 2a - Mrákotín Picek's Quarry, 2b - Mrákotín - field margin along the north-western edge of the small forest south-west of the GMS tower; 3 - Mrákotín north to north-east of the ground elevation land-mark 530.3, 3a-Mrákotín - forest north-east of the ground elevation land-mark 530.3, 3b - Mrákotín - small forest, 3c - Mrákotín - field north-east of the elevation land-mark 530.3; 4 - Mrákotín - area surroundings the unpaved road south-west of village; 5 - Oflenda - grove with a small abandoned quarry; 6 - Oldřetice - one boulder in hole excavated for fence post of private property W of settlement; 7 - Medkovy kopce - low slope of terrain step trending W-E in a small forest NNE of the elevation point $638.0 \mathrm{~m}$; $\mathrm{Kl}$ - Kladno - road-cut west of the village.

apparently affected by stronger silicification and tectonics, as documented e.g. in a small flooded quarry in the forest near Dědová ( $\left.49^{\circ} 45^{\prime} 55.3^{\prime \prime} \mathrm{N}, 15^{\circ} 59^{\prime} 34.2^{\prime \prime} \mathrm{E}\right)$. 


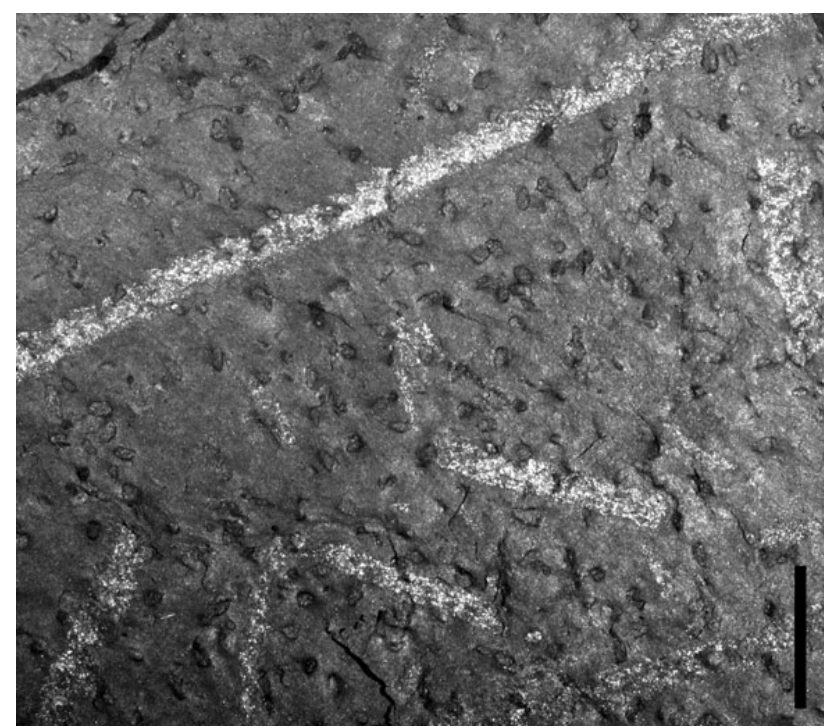

Figure 3. Porphyroblastic graphitic slate with several straight, monograptid rhabdosomes. Mrákotín, locality 3a: S 05093. Black bar represents $1 \mathrm{~cm}$.

\section{Lithology and preservation of graptolites}

The graptolites occur in dark-coloured rocks, which were originally more or less siliceous organic-rich black shales, subsequently epizonal and/or contact-metamorphosed to various degrees. As a result graphitic slates and silicites predominate. The latter lithotype of highly siliceous rocks was called lydites (e.g., Wurm 1927, Horný 1956). Despite the black colour of the rocks, TOC values range between 0.58 and $1.18 \%$ in both the slates and the silicites since the organic matter has largely decomposed in the course of Variscan tectono-metamorphic processes. Black silicites are intercalated with lenticular beds and/or flat nodules of whitish microcrystalline quartz/chalcedony, up to $20 \mathrm{~mm}$ thick. Similar, whitish lenticular beds have been observed in the lower-middle Llandovery black silicites in SE Sardinia (e.g., Riu Ollastu area sections described by Barca \& Jaeger 1990) and Holy Cross Mountains (Kremer 2005, Kremer \& Kaźmierczak 2005). Laminae rich in clastic mica appear in some siliceous slates and silicites of Aeronian age (Demirastrites triangulatus - Lituigraptus convolutus biozones). Silicites are largely absent in the Telychian succession that is predominantly composed of black slates.

All of the graptolitic strata are intensively tectonized and more or less affected by cleavage. Thick stipes of robust monograptids without any apparent thecal detail, can be found even in chiastolitic porphyroblastic slates (Fig. 3) and similar contact metamorphosed ("baked") rocks. The best preserved graptolites come predominantly from the silicites. Even though the graptolites are commonly deformed, remarkable fine details, such as slender apertural spines and ancorae, have been preserved in many specimens.
It seems that deformation preceeded silica remobilisation which gave rise to the homogeneous appearance of the rock. All silicites, including those with only slightly deformed graptolites, come from tectonized sections. The silicites form blocks resembling small plates or bricks, several centimetres (up to $20 \mathrm{~cm}$ maximum) thick. They are usually limited by bedding planes with remarkable shearing effects. Relatively competent silicified layers thus alternate with softer layers.

Sheared layers of soft slates are usually of phyllitic appearance and can be split into thin slabs. Their contact with silicites follows the bedding planes. Many such planes were apparently covered by graptolites. We suppose that graptolites were commonly concentrated on distinct bedding planes while the rocks in between were poor in fossil content. This pattern is consistent with the usual graptolite distribution in black shales. Most likely, graptolite rhabdosomes formed not only inhomogeneities in the rock but served also as a tectonic lubricant.

\section{Methods}

Due to the small-scale tectonic complexity of the Hlinsko Zone and poor exposures the graptolite material was collected mostly from loose rocks and boulders scattered in the fields and forests. The only accessible section, in the abandoned Picek's Quarry (locality 2a), exhibits black slates of late Llandovery (Telychian) age with graptolites indicating the Torquigraptus tullbergi and Oktavites spiralis biozones.

Each loose boulder collected in the fields, from small dumps along the field margins, from forested ridges and along forest trails, has been treated as a bulk sample and its fossil content was packed and studied separately in order to preserve the original graptolite taphocoenosis (referred to as an assemblage in this paper). Graptolites are hardly discernible on dry rock surface. Stones have been split wet, instantly washed and studied under a bright illumination. Of more than 300 boulders selected in the field, 212 yielded determinable and biozone-diagnostic graptolite assemblages.

The graptolite assemblages of the respective bulk samples were correlated with graptolite range charts and assemblages known from the largely continuous black shale sections of the Barrandian area of central Bohemia (Bouček 1953, Štorch 1994) and Thuringia (Schauer 1971). Also the graptolite-bearing sections of the Western Iberian Cordillera (Gutiérrez-Marco \& Štorch 1998), Bornholm (Bjerreskov 1975), English Lake District (Hutt 1974, 1975) and Wales (e.g., Zalasiewicz 1990, 1996; Loydell 1991a) and Bardo Mountains of Poland (Malinowska 1955) have been considered. Correlation even at intrazonal level with the Barrandian and Thuringia is possible for several bulk samples. Much of the original 
sedimentary succession of the Mrákotín Formation has been reconstructed as a kind of mosaic from these scattered loose boulders. Lithological types dated by graptolites have been similarly correlated with coeval rocks of the Barrandian area, Thuringia, Sardinia and West Sudetes (Bardo Mts).

The accurate identification of considerably deformed graptolite rhabdosomes required a specific approach. Qualitative characters, such as presence or absence of spines, apertural hooks and hoods, and the overall rhabdosomal and thecal architecture were of much greater importance than quantitative characters such as width and length of the thecae and rhabdosome, thecal density, etc. Some photographed specimens had to be experimentally retro-deformed by means of the Adobe-Photoshop program.

Illustrated specimens prefixed $\mathrm{S}$ have been deposited in palaeontological collections of the West Bohemian $\mathrm{Mu}-$ seum, Plzeň; specimens prefixed BB and PŠ are housed in the Czech Geological Survey, Prague.

\section{Comments on graptolite fauna and biostratigraphy}

\section{Rhuddanian}

Graptolites of Rhuddanian (early Llandovery) age were found in several boulders from mounds of stones near the Cooperative farmyard at Mrákotín, near the hill-top $530 \mathrm{~m}$ southwest of Mrákotín, and in a single boulder from West of Oldřetice (Fig. 2, localities 1, 3 and 6 respectively). Other samples, reportedly from Oflenda, have been encountered in B. Bouček's collection housed in the Czech Geological Survey, Prague.

The middle Rhuddanian Cystograptus vesiculosus Biozone has been recognized from the biozonal index taxon Cystograptus vesiculosus (Nicholson) - (single determinable rhabdosome) - associated with Normalograptus cf. normalis (Lapworth) (Fig. 8G), Dimorphograptus confertus (Nicholson) (Fig. 8M), Dimorphograptus swanstoni Lapworth (Figs 6Q, R, 8D) and Rhaphidograptus cf. extenuatus Elles \& Wood.

Normalograptus cf. rectangularis (McCoy), Dimorphograptus swanstoni, Dimorphograptoides aff. physophora (Nicholson) (Figs 6P, 8H), Rhaphidograptus toernquisti (Elles \& Wood) (Fig. 8A), Pseudorthograptus finneyi sp. nov. (Figs 6N, O, 12), "Monograptus" revolutus Kurck (sensu lato) (Figs 6L, 11B) and Pribylograptus argutus (Lapworth), associated with fragmentary Coronograptus cyphus (Lapworth) and small Coronograptus gregarius (Lapworth), indicate the Coronograptus cyphus Biozone. See Table 2 for a complete list of species.

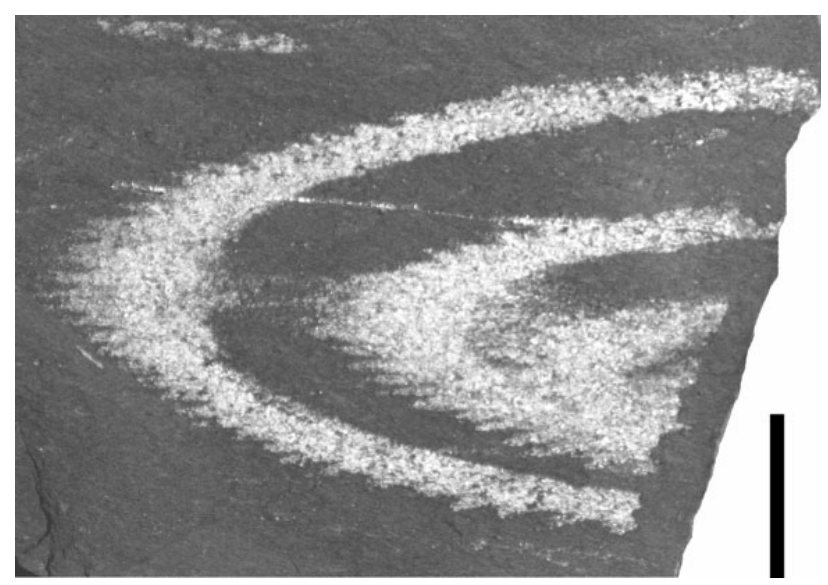

Figure 4. Oktavites spiralis (Geinitz, 1842), S 05019a; incomplete specimen from the small rock above the Picek's Quarry (locality 2a, spot 2). Black bar represents $1 \mathrm{~cm}$.

\section{Aeronian}

Aeronian (middle Llandovery) graptolites are widespread in boulders collected in the fields and neighbouring mounds of stones, in the forest and forest road near the GSM tower (hill-top $530 \mathrm{~m}$ ), all south-west of Mrákotín (Fig. 2, localities 3a, 3b). Equally common samples have been acquired from the mounds near the Cooperative farmyard at Mrákotín (locality 1). Aeronian strata probably comprise a substantial part of the entire thickness of the lower Silurian sedimentary succession of the Mrákotín Formation.

The graptolite assemblage of the Demirastrites triangulatus Biozone can be recognized by the biozonal species Demirastrites triangulatus (Harkness) (Fig. 8B) associated with Petalolithus ovatoelongatus (Kurck) (Fig. 8F), Pseudorthograptus inopinatus (Bouček), Pseudorthograptus finneyi sp. nov. (Figs 6N, O, 12), Coronograptus gregarius (Fig. 8I), Pribylograptus argutus, "Monograptus" revolutus s.l., Campograptus communis (Lapworth) (Figs 8L, 9F) and Rastrites longispinus Perner (Figs 8E, J). Pribylograptus cf. spiculiformis (Ni) (Figs 6A, 9D) - a species with robust, dorsally arcuate rhabdosome and long genicular spines - has not been found in the Barrandian area and resemble also Pribylograptus sp. of Loydell et al. (2003).

Demirastrites triangulatus, Pseudorthograptus finneyi, Pribylograptus cf. spiculiformis and "Monograptus" revolutus forms are missing in the faunal assemblages assigned to the overlying Demirastrites pectinatus Biozone (Table 2) that is distinguished most by the biozonal species Dem. pectinatus (Richter) (Figs 7B, 8C, 11J) itself.

Pseudorthograptus insectiformis (Nicholson), Petalolithus praecursor Bouček \& Přibyl (Fig. 9G) and questionable Monograptus simulans Pedersen suggest the presence of the M. simulans Biozone. 
Table 2. Graptolite species found in the individual zones. This table illustrates the wide spectrum of species recorded in the Silurian succession of the Hlinsko Zone. The list based on data published by Horný (1956) is shown in the left column; graptolites encountered in our recent research are listed in the right column. Zonal index taxa are bold typed. RA - Relative abundance of the species, assessed in this study, is shown in brackets behind the taxa: + frequent, ++ common, without cross mark - uncommon to rare, GZ - Graptolite Zone.

\begin{tabular}{|c|c|c|c|}
\hline GZ & Horný (1956) & Štorch \& Kraft (this paper) & RA \\
\hline 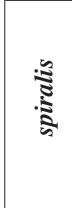 & $\begin{array}{l}\text { Retiolites geinitzianus } \\
\text { Pristiograptus } \mathrm{sp} . \\
\text { Monograptus } \mathrm{sp} . \\
\text { Monoclimacis } \mathrm{sp} . \\
\text { Spirograptus spiralis } \\
\text { Spirograptus } \mathrm{sp} .\end{array}$ & $\begin{array}{l}\text { Retiolites geinitzianus } \\
\text { Pristiograptus } \mathrm{sp} . \\
\text { Monograptus } \text { ex gr. priodon } \\
\text { Monoclimacis cf. geinitzii } \\
\text { Oktavites spiralis } \\
\text { Streptograptus } \text { cf. anguinus }\end{array}$ & $\begin{array}{l}++ \\
+ \\
+\end{array}$ \\
\hline 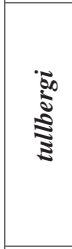 & 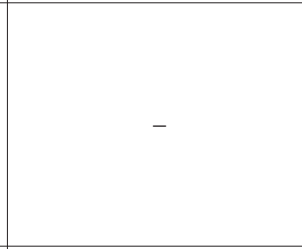 & $\begin{array}{l}\text { Retiolites geinitzianus } \\
\text { Stomatograptus imperfectus } \\
\text { Pristiograptus } \text { sp. } \\
\text { Monograptus } \text { ex gr. priodon } \\
\text { Monoclimacis cf. crenulata } \\
\text { Cochlograptus veles } \\
\text { Torquigraptus tullbergi }\end{array}$ & \\
\hline 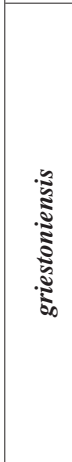 & - & \begin{tabular}{|l} 
Retiolites geinitzianus / \\
angustidens \\
Monograptus ex gr. priodon \\
Monoclimacis ex gr. \\
griestoniensis \\
Streptograptus sartorius? \\
Pseudostreptograptus? aff. \\
loydelli \\
Cochlograptus veles \\
Torquigraptus cf. arcuatus \\
Torquigraptus aff. proteus \\
Torquigraptus pragensis \\
Torquigraptus australis \\
Diversograptus sp.
\end{tabular} & $\begin{array}{l}+ \\
+ \\
+\end{array}$ \\
\hline 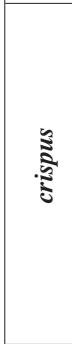 & $\begin{array}{l}\text { Globosograptus cf. crispus } \\
\text { Monograptus veles }\end{array}$ & $\begin{array}{l}\text { Parapetalolithus sp. (cf. tenuis) } \\
\text { Pseudoplegmatograptus ex gr. } \\
\text { obesus } \\
\text { Pristiograptus } \text { sp. } \\
\text { Monograptus } \text { ex gr. priodon } \\
\text { Torquigraptus proteus } \\
\text { Streptograptus crispus } \\
\text { Streptograptus } \text { cf. storchi } \\
\text { Cochlograptus veles } \\
\text { Spirograptus turriculatus }\end{array}$ & $\begin{array}{l}+ \\
+ \\
+ \\
+ \\
+ \\
+\end{array}$ \\
\hline 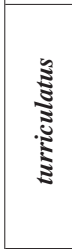 & - & $\begin{array}{l}\text { Parapetalolithus tenuis } \\
\text { Pristiograptus ex gr. } \text { nudus } \\
\text { Monograptus marri } \\
\text { Streptograptus } \text { cf. storchi } \\
\text { Streptograptus exiguus } \\
\text { Streptograptus } \text { sp. (tiny form) } \\
\text { Spirograptus turriculatus }\end{array}$ & ++ \\
\hline 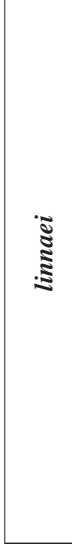 & - & $\begin{array}{l}\text { Glyptograptus sp. (cf. "Orth. } \\
\text { ultimus") } \\
\text { Parapetalolithus ovatus } \\
\text { Parapetalolithus regius } \\
\text { Parapetalolithus cf. elongatus } \\
\text { Parapetalolithus palmeus? } \\
\text { Parapetalolithus } \text { cf. hispanicus } \\
\text { Pseudoretiolites? sp. } \\
\text { Pristiograptus regularis } \\
\text { Pristiograptus cf. variabilis } \\
\text { Pristiograptus pristinus } \\
\text { Streptograptus plumosus } \\
\text { Streptograptus sp. (tiny form) } \\
\text { Streptograptus cf. storchi } \\
\text { ?Diversograptus cf. capillaris } \\
\text { Stimulograptus becki }\end{array}$ & + \\
\hline
\end{tabular}

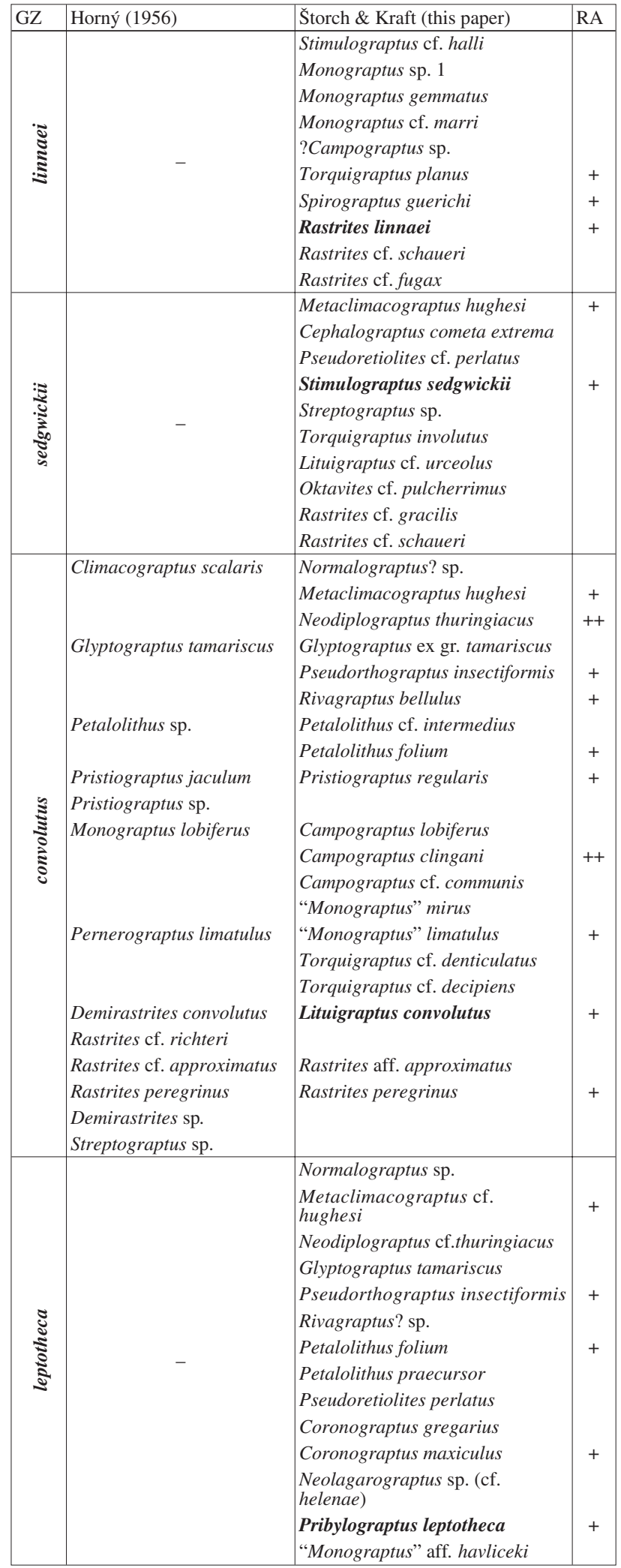


Table 2 continued

\begin{tabular}{|c|c|c|c|}
\hline GZ & Horný (1956) & Štorch \& Kraft (this paper) & RA \\
\hline 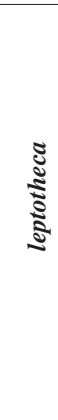 & - & $\begin{array}{l}\text { Pribylograptus leptotheca } \\
\text { "Monograptus" aff. havliceki } \\
\text { "Monograptus"limatulus } \\
\text { "Monograptus" mirus } \\
\text { "Monograptus" dracocephalus } \\
\text { Campograptus lobiferus } \\
\text { Campograptus communis } \\
\text { Campograptus millepeda } \\
\text { "Monograptus" paradenticulatus } \\
\text { Lituigraptus richteri } \\
\text { Rastrites approximatus } \\
\text { Rastrites cf. geinitzii }\end{array}$ & ++ \\
\hline 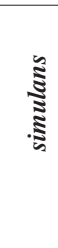 & - & $\begin{array}{l}\text { Normalograptus aff. normalis } \\
\text { Pseudorthograptus insectiformis } \\
\text { Petalolithus praecursor } \\
\text { Coronograptus gregarius } \\
\text { ?"Monograptus simulans” } \\
\text { Torquigraptus cf. valens } \\
\text { Lituigraptus cf. richteri }\end{array}$ & \\
\hline 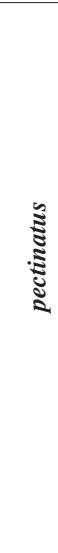 & $\begin{array}{l}\text { Climacogr. rectangularis } \\
\text { Climacograptus } \mathrm{sp} . \\
\text { Glyptograptus } \mathrm{cf} \text {. sinuatus } \\
\text { Orthograptus } \mathrm{sp} . \\
\text { Petalo. ovatoelongatus } \\
\text { Petalolithus } \mathrm{cf} . \text { minor } \\
\text { Monograptus } \mathrm{sp} . \\
\text { Demirastrites } \mathrm{sp} . \\
\text { Rastrites longispinus }\end{array}$ & $\begin{array}{l}\text { Normalograptus } \text { sp. } \\
\text { Metaclimacograptus sp. } \\
\text { Neodiplograptus } \text { cf. thuringiacus } \\
\text { Rhaphidograptus toernquisti } \\
\text { Glyptograptus } \text { sp. } \\
\text { Petalolithus ovatoelongatus } \\
\text { Pseudoretiolites cf. perlatus } \\
\text { Pristiograptus concinnus } \\
\text { Coronograptus gregarius } \\
\text { Pribylograptus argutus } \\
\text { Pribylograptus } \text { cf. sandersoni } \\
\text { "Monograptus" cf. sudburiae } \\
\text { Campograptus aff. communis } \\
\text { Demirastrites pectinatus } \\
\text { Rastrites cf. longispinus }\end{array}$ & $\begin{array}{l}++ \\
++\end{array}$ \\
\hline 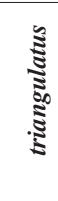 & - & $\begin{array}{l}\text { Normalograptus } \text { cf. normalis } \\
\text { Normalograptus nikolayevi } \\
\text { Metaclimacograptus hughesi } \\
\text { Metaclimacograptus cf. undulatus } \\
\text { Neodiplograptus } \mathrm{cf} . \\
\text { thuringiacus }\end{array}$ & + \\
\hline
\end{tabular}

The Pribylograptus leptotheca Biozone is widely represented in our material. It is distinguished by a co-occurrence of Pribylograptus leptotheca (Lapworth) (Fig. 9J), Petalolithus folium (Hisinger) (Fig. 9C), Petalolithus praecursor, "Monograptus" paradenticulatus Zalasiewicz (Fig. 9B), Lituigraptus richteri (Perner) (Fig. 6I), Coronograptus maxiculus Štorch, Monograptus aff. havliceki Štorch, Monograptus dracocephalus Štorch, Campograptus lobiferus (McCoy) (Fig. 9K), Campograptus leptotheca (McCoy) (Figs 7A, 11D) and Rastrites approximatus Perner. The full diversity listed in Tab. 2 echoes that published by Štorch (1998) from Tmaň in the Barrandian area.

The Lituigraptus convolutus Biozone manifests itself by a co-occurrence of Lituigraptus convolutus (Hisinger) (Figs 9A, I), Rivagraptus bellulus (Törnquist) (Figs 6M,

\begin{tabular}{|c|c|c|c|}
\hline GZ & Horný (1956) & Štorch \& Kraft (this paper) & RA \\
\hline \multirow{15}{*}{ 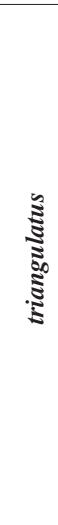 } & \multirow{15}{*}{ - } & Neodiplograptus cf. thuringiacus & + \\
\hline & & Glyptograptus tamariscus & \\
\hline & & Rhaphidograptus toernquisti & ++ \\
\hline & & Pseudorthograptus finneyi & \\
\hline & & Pseudorthograptus inopinatus? & \\
\hline & & Petalolithus ovatoelongatus & \\
\hline & & Pristiograptus concinnus? & \\
\hline & & Coronograptus gregarius & ++ \\
\hline & & Pribylograptus argutus & + \\
\hline & & Demirastrites triangulatus & ++ \\
\hline & & Rastrites longispinus & + \\
\hline & & "Monograptus" revolutus s.l. & + \\
\hline & & "Monograptus" ex gr. austerus & \\
\hline & & Pribylograptus $\mathrm{cf}$ spiculiformis & \\
\hline & & Campograptus communis & + \\
\hline \multirow{16}{*}{$\frac{\mathfrak{3}}{\frac{3}{3}}$} & \multirow{16}{*}{-} & $\begin{array}{l}\text { Normalograptus } \mathrm{cf} . \\
\text { rectangularis }\end{array}$ & \\
\hline & & Normalograptus cf. normalis & \\
\hline & & Normalograptus cf. medius & \\
\hline & & Metaclimacograptus sp. & \\
\hline & & Neodiplograptus cf. elongatus & \\
\hline & & Glyptograptus cf. tamariscus & \\
\hline & & Pseudorthograptus finneyi & \\
\hline & & $\begin{array}{l}\text { Dimorphograptoides aff. } \\
\text { physophora }\end{array}$ & \\
\hline & & Rhaphidograptus toernquisti & + \\
\hline & & Dimorphograptus swanstoni & + \\
\hline & & Dimorphograptus erectus & \\
\hline & & Coronograptus cyphus & + \\
\hline & & Huttagraptus? sp. & \\
\hline & & Coronograptus gregarius & \\
\hline & & Pribylograptus argutus & \\
\hline & & "Monograptus" revolutus s.l. & \\
\hline \multirow{8}{*}{ 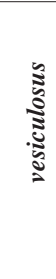 } & \multirow{8}{*}{-} & Normalograptus ex gr. normalis & \\
\hline & & Rhapidograptus cf. extenuatus & \\
\hline & & Rhaphidograptus cf. toernquisti & \\
\hline & & Cystograptus vesiculosus & \\
\hline & & Dimorphograptus swanstoni & + \\
\hline & & Dimorphograptus confertus & + \\
\hline & & Atavograptus? sp. & \\
\hline & & "Monograptus" cf. austerus & \\
\hline
\end{tabular}

9H), "Monograptus" limatulus Törnquist, "Monograptus" mirus Perner (Fig. 6C), Campograptus clingani (Carruthers) (Figs 7D, 11H), Torquigraptus cf. denticulatus (Törnquist) and Rastrites peregrinus Barrande (Fig. 9L). Examination of the specimens housed in the National $\mathrm{Mu}-$ seum, Prague confirms convolutus Biozone assignment of the fauna reported by Horný (1956).

The Stimulograptus sedgwickii Biozone is the least represented Aeronian biozone in our collections. Stimulograptus sedgwickii (Portlock) is accompanied by Metaclimacograptus hughesi (Nicholson), a single rhabdosome of Cephalograptus cometa extrema Bouček \& Přibyl, Oktavites cf. pulcherrimus (Manck), fragmentary Lituigraptus cf. urceolus (Richter), Rastrites cf. gracilis Přibyl, fragmentary Torguigraptus involutus 
BARRANDIAN AREA

HLINSKO ZONE

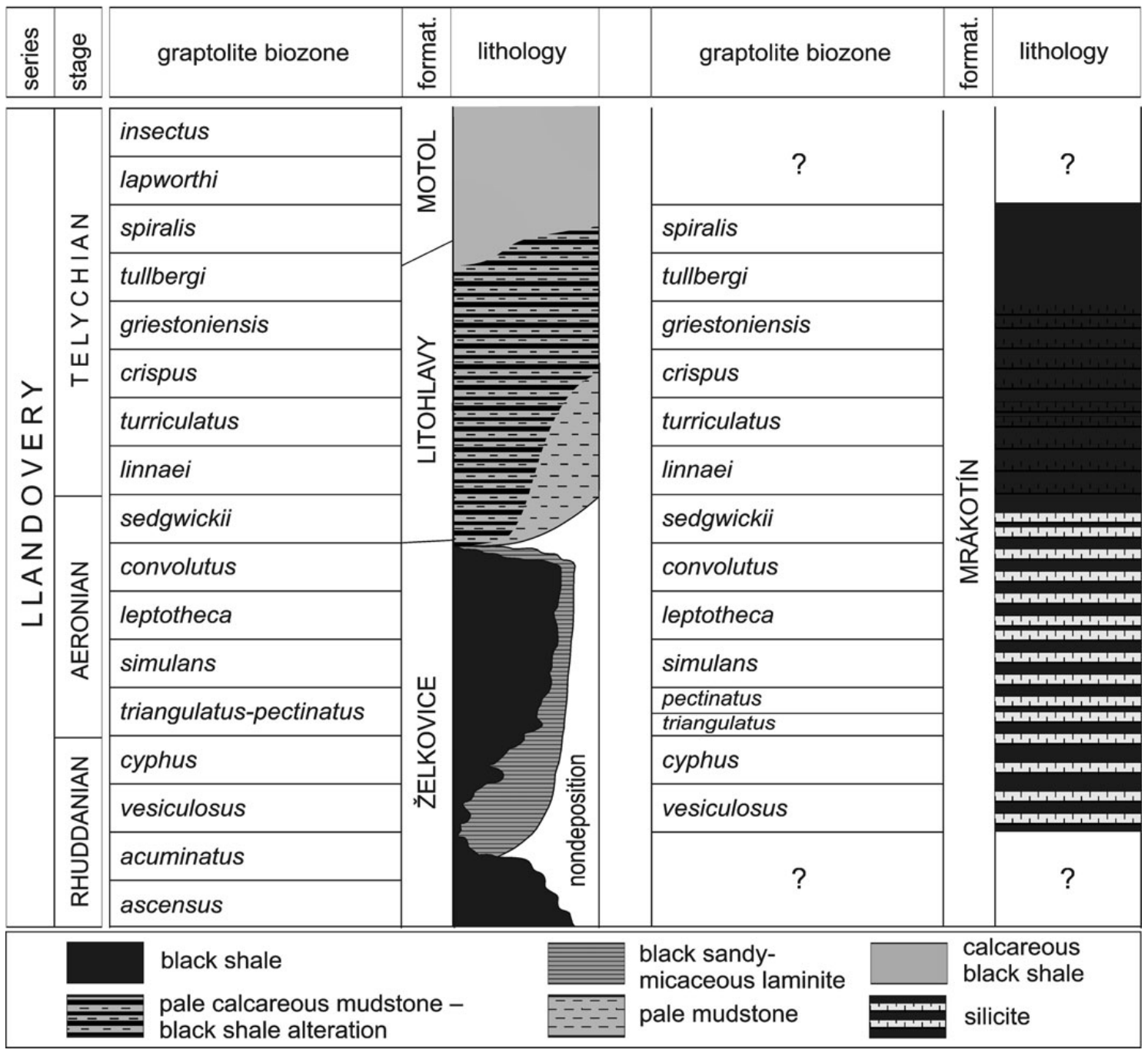

Figure 5. A comparison between the sedimentary succession of the Mrákotín Formation of the Hlinsko Zone and the sedimentary succession of the Barrandian area based upon biostratigraphic correlation.

(Lapworth) (Fig. 11A) and Streptograptus sp. A similar assemblage with late lituigraptids and early oktavitids has been widely reported from deep-water Thuringian sections (e.g., Schauer 1971) but it is either missing or poorly represented in the Barrandian area.

\section{Telychian}

Telychian (late Llandovery) graptolites are common from our sampling sites. Lower and middle Telychian samples are from the fields, neighbouring mounds of stones, the fo-

Figure 6. A - Pribylograptus cf. spiculiformis (Ni, 1978), S 05052a. • B - Torquigraptus proteus (Barrande, 1850), S 05086. • C - "Monograptus" mirus Perner, 1897, S 05076. D Dimorphograptus erectus Elles \& Wood, 1908, S 05072. E - Metaclimacograptus hughesi (Nicholson, 1869), S 05088. - F-H - Torquigraptus pragensis (Přibyl, 1943); F - S 05049, G - S 05047, H - S 05025. • I - Lituigraptus richteri (Perner, 1897$)$, S 05092. - J -Huttagraptus? sp. A, S 05041. - K - Pseudostreptograptus? aff. loydelli (Štorch \& Serpagli, 1993) sensu Zalasiewicz (1994), S 05031. -L - "Monograptus" revolutus Kurck, 1882, s.1., S 05089. • M - Rivagraptus bellulus (Törnquist, 1890), S 05067. • N, O - Pseudorthograptus finneyi sp. nov.; N-BB 718, O - S 05077. • P - Dimorphograptoides aff. physophora (Nicholson, 1868), BB 719a. $\bullet$ Q, R - Dimorphograptus swanstoni Lapworth, 1876; Q - BB 720, R - S 05078. • A-I, K-M, R - Mrákotín, locality 3a: (A, E, L) triangulatus Biozone, (B) crispus Biozone, (C, I) leptotheca Biozone, (D) cyphus Biozone, (F-H, K) griestoniensis Biozone, (I) simulans Biozone, (M) convolutus Biozone and (R) vesiculosus Biozone. • J, O - Mrákotín, locality 1: (J) triangulatus Biozone and $(\mathrm{O})$ cyphus Biozone. $\bullet \mathrm{N}, \mathrm{P}, \mathrm{Q}-$ Oflenda (exact site unknown): vesiculosus Biozone. All specimens $\times 6$. Black bars show the direction of tectonic elongation. 
Petr Štorch \& Petr Kraft • Graptolite of the lower Silurian Mrákotín Formation, Hlinsko Zone

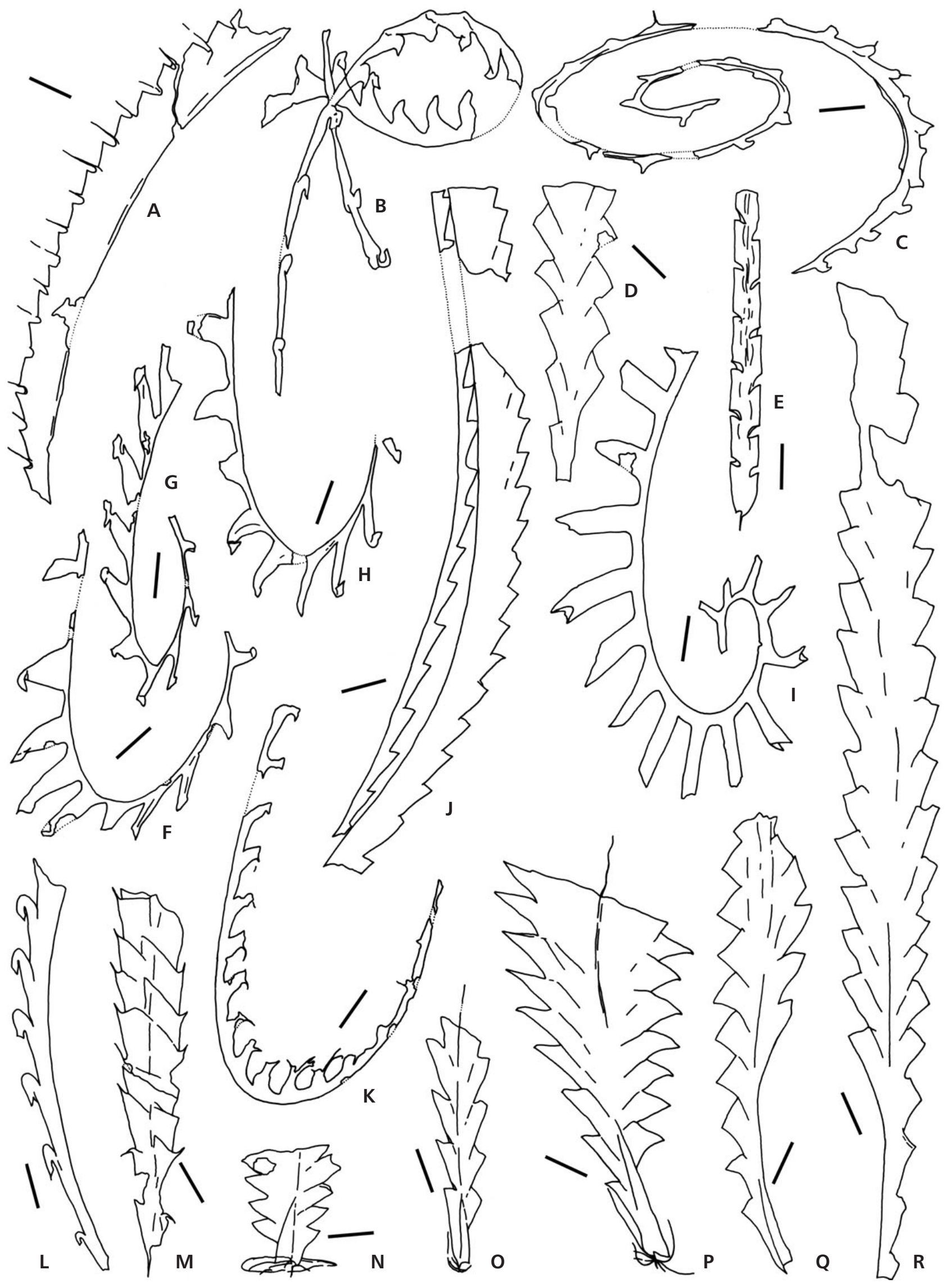




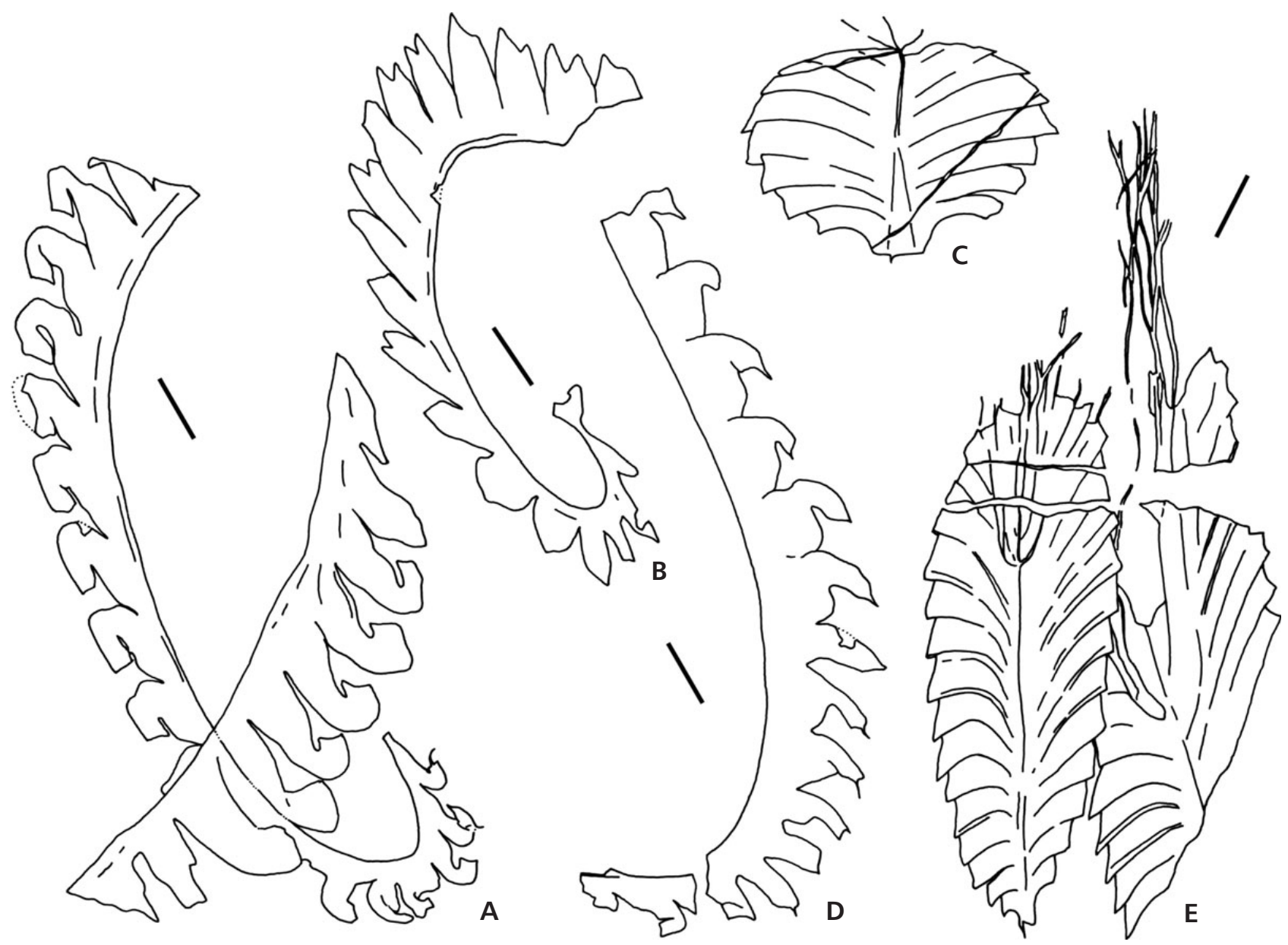

Figure 7. A - Campograptus millepeda (McCoy, 1850), S 05083a. • B - Demirastrites pectinatus (Richter, 1853), S 05084. • C - Parapetalolithus ovatus (Barrande, 1850), S 05032. • D - Campograptus clingani (Carruthers, 1867), S 05080. • E - Parapetalolithus regius (Hundt, 1957$)$, S 05007. - A, B - Mrákotín, locality 1: (A) leptotheca Biozone and (B) pectinatus Biozone. • C-E - Mrákotín, locality 3a: (D) convolutus Biozone and (C, E) linnaei Biozone. $\mathrm{A}-\mathrm{D} \times 6, \mathrm{E} \times 3$. Black bars show the direction of tectonic elongation.

rested ridge and forest road near the GSM tower (hill-top $530 \mathrm{~m}$ ) south-west of Mrákotín (Fig. 2, localities 2b, 3a-c, 4). Further Telychian graptolites come from mounds near the Cooperative farmyard at Mrákotín (locality 1).

The most diverse assemblage is from the Rastrites linnaei Biozone, which is in accordance with the graptolite diversity high observed by Melchin et al. (1998). Rastrites linnaei Barrande (Fig. 10H) occurs together with Parapetalolithus ovatus (Barrande) (Figs 7C, 10B),
Parapetalolithus regius (Hundt) (Figs 7E, 11K), Parapetalolithus elongatus (Bouček \& Přibyl), Parapetalolithus cf. palmeus (Barrande), "Monograptus" gemmatus (Barrande), Streptograptus plumosus (Baily), Stimulograptus halli (Barrande) (Fig. 10L), Stimulograptus becki (Barrande), Torquigraptus planus (Barrande) (Fig. 10M), Spirograptus guerichi Loydell, Štorch \& Melchin (Fig. 10E), Rastrites cf. fugax (Barrande), Rastrites cf. schaueri Štorch \& Loydell a.o. We adopted Rastrites

Figure 8. A - Rhaphidograptus toernquisti (Elles \& Wood, 1906), S 05059. • B Demirastrites triangulatus (Harkness, 1851), S 05017. • C - Demirastrites pectinatus (Richter, 1853), S 05038. • D - Dimorphograptus swanstoni Lapworth, 1876, BB 720. • E, J - Rastrites longispinus Perner, 1897; E - S 05055, J - S 05099. • F - Petalolithus ovatoelongatus (Kurck, 1882), S 05053. • G - Normalograptus cf. normalis (Lapworth, 1877), BB 722. • H -Dimorphograptoides aff. physophora (Nicholson, 1868), BB 719a. • I - Coronograptus gregarius (Lapworth, 1876 ), S 05016. - K - Neodiplograptus thuringiacus (Kriste, 1919) and Pribylograptus leptotheca (Lapworth, 1876), S 05064. • L - Campograptus communis (Lapworth, 1876), S 05002. • M - Dimorphograptus confertus (Nicholson, 1868), S 05061.・D, G, H - Oflenda (exact site unknown): vesiculosus Biozone. • B, F, I, J, L - Mrákotín, locality 1: triangulatus Biozone. • A, C, E, K - Mrákotín, locality 3a: (A) triangulatus Biozone, (C, E) pectinatus Biozone and $(\mathrm{K})$ convolutus Biozone. $\bullet \mathrm{M}$ - Oldřetice, locality 6 : vesiculosus Biozone. All specimens $\times 4$. White bars show the direction of tectonic elongation. 
Petr Štorch \& Petr Kraft • Graptolite of the lower Silurian Mrákotín Formation, Hlinsko Zone
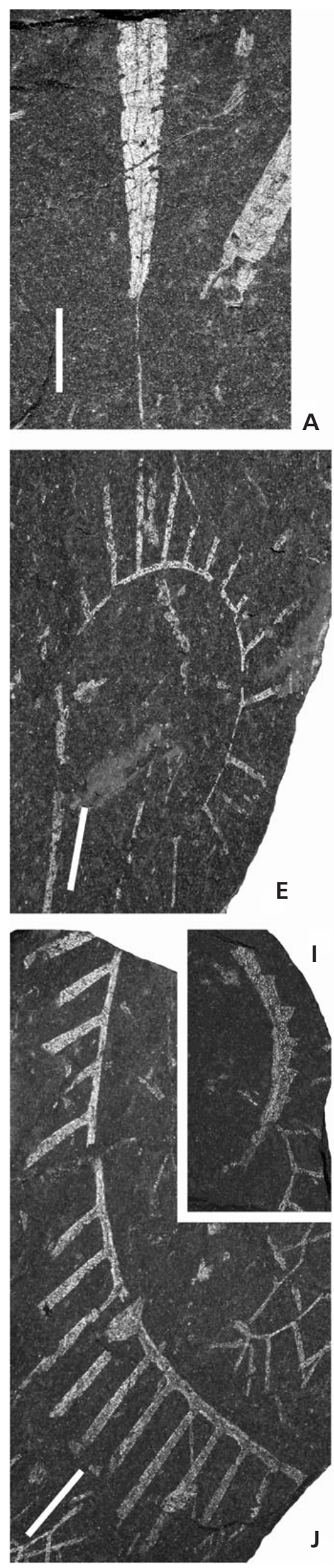
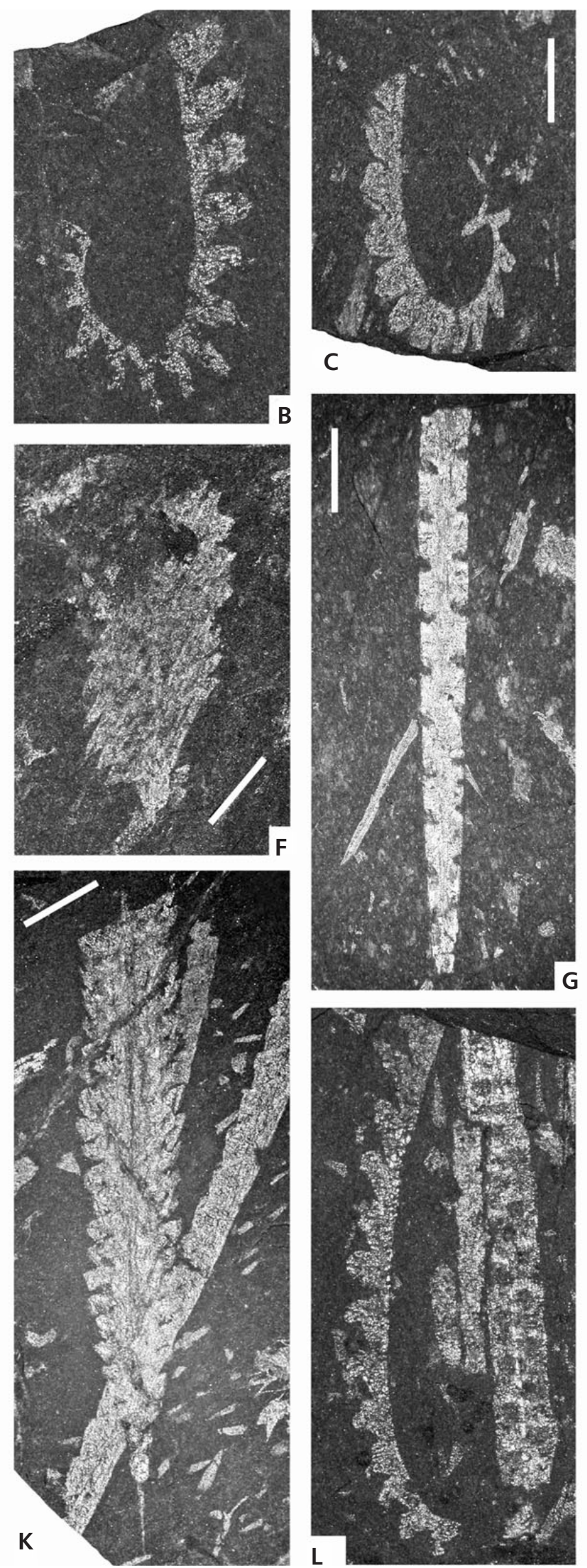
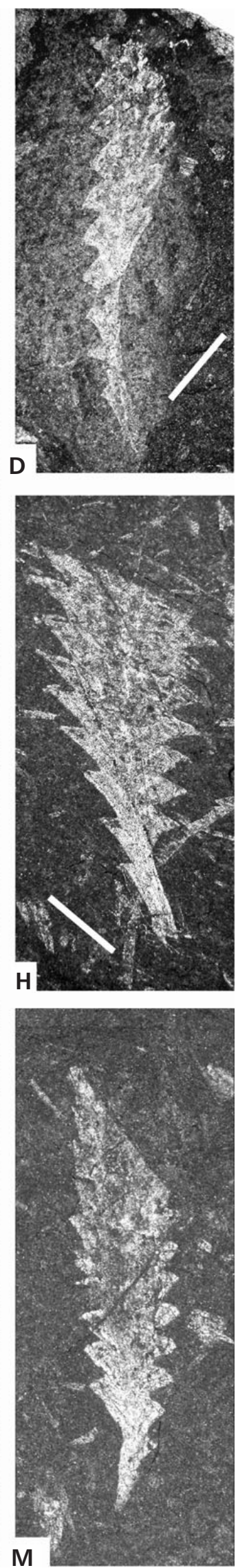
linnaei as a biozonal index taxon instead of Spirograptus guerichi despite the relative scarcity of the former species in our samples. The Rastrites linnaei Biozone has been well defined in the Barrandian area (Bouček 1953, Storch 1994), Thuringia (Schauer 1971) and Spain (Gutiérrez-Marco \& Storch 1998). It is well developed in Poland (Malinowska 1955) and Sardinia (Štorch \& Serpagli 1993). Spirograptus guerichi is the preferred zonal index fossil outside Europe where Rastrites linnaei is missing. Loydell (1991a) recorded first occurrences of Rastrites linnaei well below the first Spirograptus guerichi in Wales. However, Spirograptus guerichi is hardly distinguishable from Spirograptus turriculatus (Barrande) (Figs 10K, 11I) - (index species of the succeeding zone) in tectonically broadened and deformed material, such as that from the Hlinsko Zone.

A much impoverished graptolite fauna characterizes the Spirograptus turriculatus Biozone. In the present samples the biozonal index species has been associated with Parapetalolithus tenuis (Barrande) (Fig. 10C), Monograptus marri Barrande and some streptograptids, notably Streptograptus exiguus (Lapworth). Close examination of the specimen figured as Spirograptus spiralis by Horný (1956) revealed that it has spirograptid thecae with long apertural spines. The specimen is a tectonically enlarged Spirograptus turriculatus.

The graptolite fauna of the Streptograptus crispus Biozone is characterized by the presence of common Cochlograptus veles (Richter) along with rare Streptograptus crispus (Lapworth), Streptograptus storchi Loydell, Torquigraptus proteus (Barrande) (Figs 6B, 11E), Pseudoplegmatograptus ex gr. obesus Lapworth and Spirograptus turriculatus (Barrande) (Figs 10K, 11I), the latter persisting from the underlying biozone (see Table 2 for full list of species). The considerably overlapping ranges of Spirograptus turriculatus and Streptograptus crispus were first recorded by Elles \& Wood (1913, p. 439), in the Barrandian area by Štorch (1994).

The Monoclimacis griestoniensis Biozone has been identified by means of the co-occurrence of Retiolites geinitzianus angustidens Elles \& Wood (Fig. 10I), Monoclimacis ex gr. griestoniensis Nicol, Pseudostreptograptus? aff. loydelli Štorch \& Serpagli, sensu Zalasiewicz (1994) (Figs 6K, 10F), Cochlograptus veles (Richter) (Fig. 10D), Torquigraptus cf. arcuatus (Bou- ček), Torquigraptus australis Štorch (Fig. 10A) and rather common Torquigraptus pragensis (Přibyl) (Figs 6F-H, 10G, 11F). The last named species is known to be a prominent, although uncommon component of the Monoclimacis griestoniensis Biozone assemblages in the Barrandian area (Bouček 1953), Thuringia (Schauer 1971), Sardinia (Štorch \& Serpagli 1993) and Wales (Zalasiewicz 1990).

Graptolites assigned to the Torquigraptus tullbergi Biozone have been found in several loose boulders and in the middle part of the black slate succession exposed in Picek's Quarry (Fig. 2, locality 2a). Uncommon Torquigraptus tullbergi (Bouček) is associated with Retiolites geinitzianus (Barrande), Stomatograptus imperfectus Bouček \& Münch - (a single large rhabdosome, Fig. 10J), Monograptus ex gr. priodon (Bronn), Cochlograptus veles (Fig. 10J) and Monoclimacis cf. crenulata (Elles \& Wood).

The highest biostratigraphically proven beds are exposed in the uppermost part of the Picek's Quarry (locality 2a, spot 2). Rare, large specimens of Oktavites spiralis (Geinitz) (Fig. 4) are confined to a few bedding planes, associated with Retiolites geinitzianus and Streptograptus cf. anguinus Přibyl. Straight rhabdosomes of Monograptus, Monoclimacis and Pristiograptus are common throughout the succession.

Although Horný (1956) and the present authors have recorded graptolite bearing slabs in different frequency from different stratigraphic levels, a very good overlap is notable (Table 1). It is evident that only lower Silurian rocks are represented in the Mrákotín Formation. We have proved the Llandovery Series. Horný (1956) mentioned also the lowermost Wenlock from this unit, but we have found no material of e.g. cyrtograptids to confirm his opinion.

\section{Palaeontological notes}

\section{Rivagraptus bellulus (Törnquist, 1890)}

This is a common constituent of the Lituigraptus convolutus Biozone assemblage and also occurs in the Pribylograptus leptotheca Biozone in the Hlinsko area. Specimens with proximal ends can be easily recognized by their sub-alternating, straight tubular thecae and thecal apertures furnished with prominent spines (Figs 6M, 9H). Only one

Figure 9. A, I-Lituigraptus convolutus (Hisinger, 1837); A - S 05068, I-S 05065. • B “Monograptus" paradenticulatus Zalasiewicz, 1996, S 05066. - C - Petalolithus folium (Hisinger, 1837), S 05023. D - Pribylograptus cf. spiculiformis (Ni, 1978), S 05052a. • E -Metaclimacograptus hughesi (Nicholson, 1869), S 05073. • F - Campograptus communis (Lapworth, 1876), S 05062. • G - Petalolithus praecursor Bouček \& Přibyl, 1941 , S 05011. - H - Rivagraptus bellulus (Törnquist, 1890), S 05067. • J - Pribylograptus leptotheca (Lapworth, 1876), S 05060. • K - Campograptus lobiferus (McCoy, 1850), S 05076. • L -Rastrites peregrinus Barrande, 1850, S 05063. • A, F - Mrákotín, locality 1: (A) convolutus Biozone and (F) triangulatus Biozone. • B-E, G-L-Mrákotín, locality 3a: (B, G, J) leptotheca Biozone; (C, E, H, I, K, L) convolutus Biozone and (D) triangulatus Biozone. All specimens $\times 4$. White bars show the direction of tectonic elongation. 
Petr Štorch \& Petr Kraft • Graptolite of the lower Silurian Mrákotín Formation, Hlinsko Zone
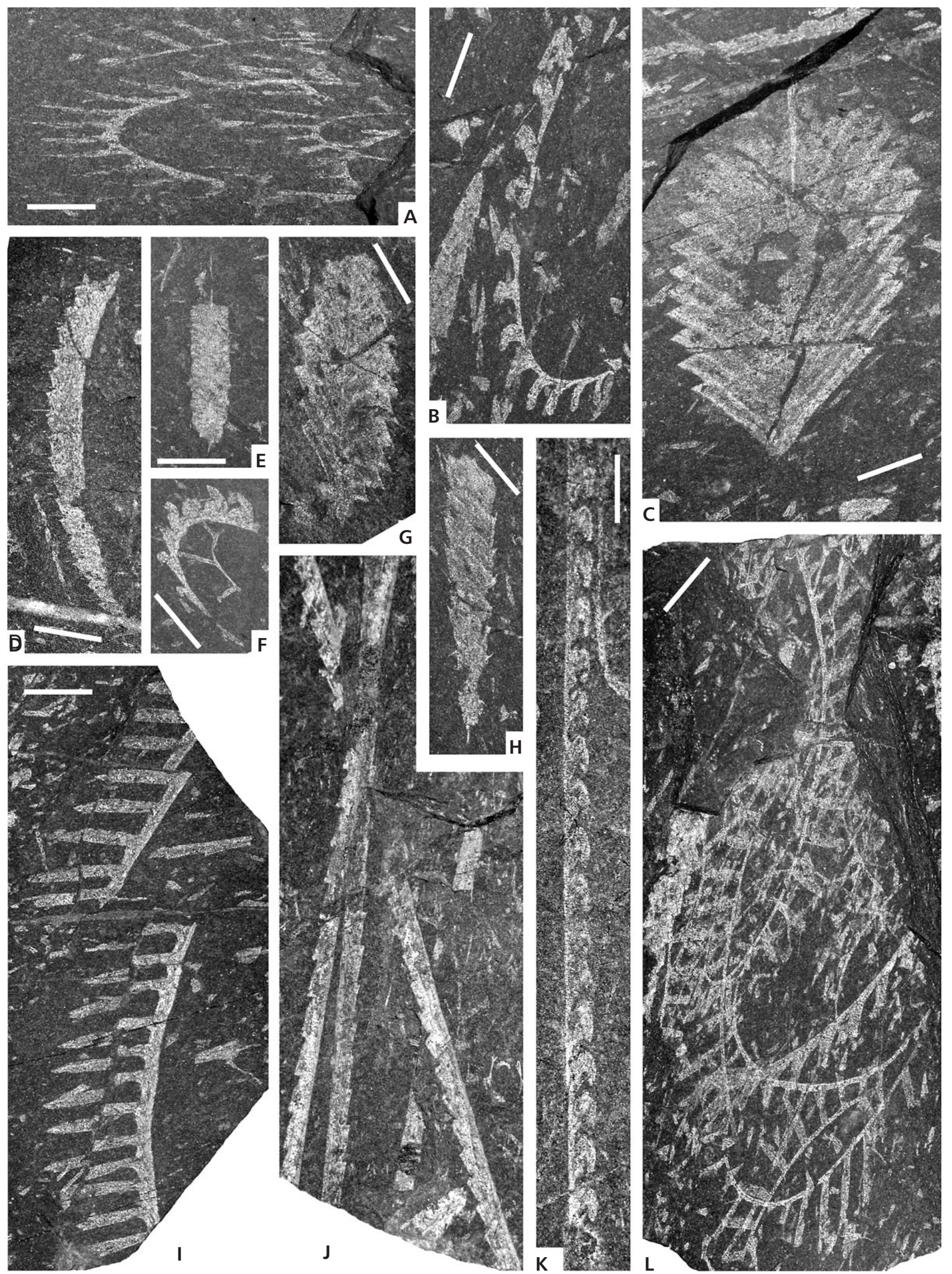
of the paired spines is usually seen. A robust, long virgella is another typical feature of this species. Species lacking proximal ends would be difficult, if not impossible, to distinguish from Agetograptus primus (see Loydell 1991b).

\section{Parapetalolithus ovatus (Barrande, 1850)}

This species is nearly circular in outline until the maturity of the rhabdosome is achieved. Proximal thecae are tightly appressed and concave to the proximal end of the rhabdosome. The maximum width of $6.6 \mathrm{~mm}$ is attained at the $4-5^{\text {th }}$ thecal pair. The specimen figured on Figs 7C and 10B is furnished with several nemal threads - a feature more typical of Parapetalolithus regius below. Similar nemal threads were recorded in Parapetalolithus ovatus by Loydell (1992).

\section{Parapetalolithus regius (Hundt, 1957)}

Two broadly ovoid rhabdosomes were found in the Rastrites linnaei Biozone. The maximum rhabdosome width of $7.8 \mathrm{~mm}$ is attained approximately at the level of the ninth thecal pair. The thecae are closely spaced and, proximally, concave to the proximal end. The distal end of the rhabdosome divides in two parts with a bundle of nemal threads. This division is complete in one specimen and just initiated in the other one (Figs 7E, 11K). The present specimens agree well with the earlier descriptions of Parapetalolithus regius by Loydell (1992) and those of its junior synonym Parapetalolithus ovatus scopaecularis (Schauer, 1971).

\section{Dimorphograptoides aff. physophora (Nicholson, 1868)}

A robust rhabdosome with short uniserial portion comprising th $1^{1}$. Th $1^{2}$ is either missing or much delayed in its budding. The sicula is long, exposed for $c a$ two-thirds its length on the dorsal side. It is furnished with a large, poorly preserved, probably four-pronged ancora (see Figs $6 \mathrm{P}, 8 \mathrm{H}$ ). The straight thecae are acuminate in outline, with ventrally extended apertures, roughly perpendicular to the rhabdosome. Th $1^{1}$ turns up below the sicular aperture and, combined with either delayed or even suppressed th $1^{2}$, long sicula and large ancora, accounts for proximal growth of Pattern I or derived Pattern I' sensu Melchin (1998). The similar proximal development of Pseudorthograptus? alaskensis (Churkin \& Carter, 1970) and Pseudorthograptus? physophora (Nicholson, 1868), differs in having a more advanced ancora with connecting rods and membrane. Present form well matches Barrandian specimens, assigned to Pseudorthograptus obuti (Rickards \& Koren', 1974) by Štorch (1985, fig. 2H, J), by its protracted proximal end, much exposed sicula and delayed th $1^{2}$. It also occurs in the Coronograptus cyphus Biozone although in its lower part, in association with $\mathrm{Ne}$ odiplograptus cf. elongatus, Dimorphograptus swanstoni and Rhaphidograptus toernquisti. True Pseudorthograptus obuti (Rickards \& Koren', 1974) can be distinguished from all of these forms by its regular pattern I proximal development without uniserial part (see also Rickards \& Koren’ 1996).

\section{Dimorphograptus erectus Elles \& Wood, 1908}

Several dimorphograptid rhabdosomes possess a short uniserial portion comprising two thecae. The distal width of the rhabdosome, 2.5-2.8 $\mathrm{mm}$, is attained rapidly, although without abrupt expansion at the beginning of the biserial portion (Fig. 6D). Straight thecae with perpendicular or slightly everted apertures overlap for about half their length. Dimorphograptus erectus nicholsoni Rickards, 1970 distinguished by its two-three uniserial thecae has been synonymized with the type subspecies $D$. erectus erectus Elles \& Wood, 1908 by Hutt (1974). Actually, the two forms have been separated by the slightly different number of uniserial thecae, which often varies in dimorphograptids. Dimorphograptus cf. longissimus (Kurck, 1882) described by Hutt (1974) has an equally short uniserial part but a wider biserial part with expanded thecal apertures. The Hlinsko Zone Dimorphograptus cf. erectus is accompanied by Dimorphograptus swanstoni, Rhaphidograptus toernquisti, Monograptus austerus and Coronograptus cyphus?.

\footnotetext{
Figure 10. A - Torquigraptus australis Štorch, 1998, S 05021. • B - Parapetalolithus ovatus (Barrande, 1850), S 05032. • C - Parapetalolithus tenuis (Barrande, 1850), S 05074. • D (and J) - Cochlograptus veles (Richter, 1871), S 05050. • E - Spirograptus guerichi Loydell, Štorch \& Melchin, 1993, S 05090. • F - Pseudostreptograptus? aff. loydelli (Štorch \& Serpagli, 1993) sensu Zalasiewicz (1994), S 05031. • G - Torquigraptus pragensis (Přibyl, 1943), S 05049. • H - Rastrites linnaei Barrande, 1850, S 05069. • I - Retiolites angustidens Elles \& Wood, 1908, S 05022. • J - Stomatograptus imperfectus Bouček \& Münch, 1944, and Cochlograptus veles (Richter, 1871), S 05020. • K - Spirograptus turriculatus (Barrande, 1850 ), S 05027. - L - Stimulograptus halli (Barrande, 1850), S 05091. • M - Torquigraptus planus (Barrande, 1850), S 05033. • (B, E, H, L, M) linnaei Biozone; (C, K) turriculatus Biozone; (D) crispus Biozone; (A, F, G, I) griestoniensis Biozone; (J) tullbergi Biozone; all from Mrákotín, locality 3a. All specimens $\times 4$, except Fig. $10 \mathrm{~J}, \times 2$. White bars show the direction of tectonic elongation.
} 
Petr Štorch \& Petr Kraft • Graptolite of the lower Silurian Mrákotín Formation, Hlinsko Zone
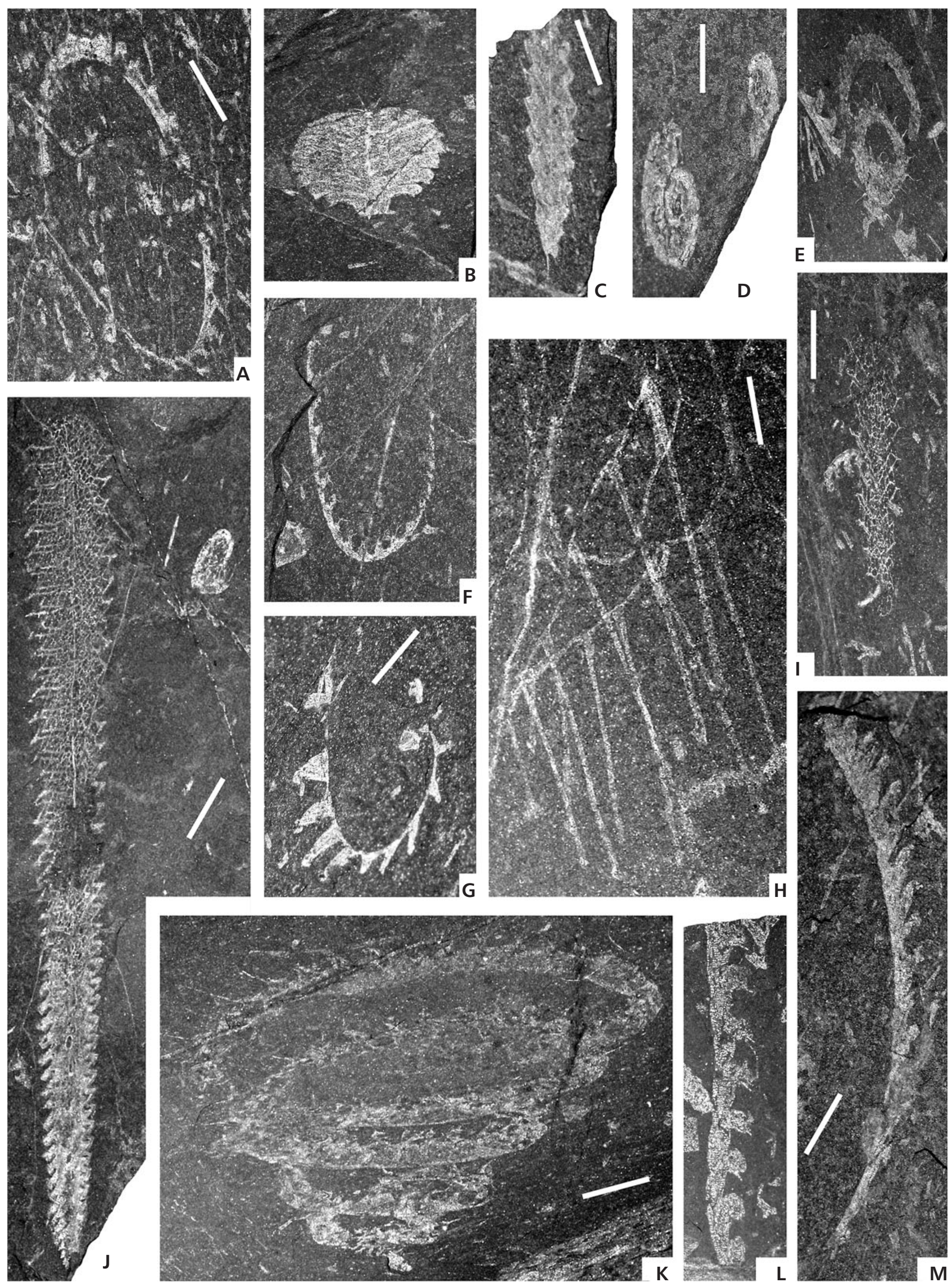


\section{Dimorphograptus swanstoni Lapworth, 1876}

Specimens are distinguished by acuminate, glyptograptid thecae without apertural extension and by a uniserial part that consists of 3-5 thecae (Figs 6Q, R, 8D). The uniserial part is longer and comprises more thecae than that of Dimorphograptus erectus Elles \& Wood or Dimorphograptus longissimus (Kurck). Dimorphograptus confertus is readily discernible by its wider rhabdosome and slightly more closely spaced thecae with thickened and extended apertural lips. Dimorphograptus swanstoni occurs in the lower part of the Coronograptus cyphus Biozone in association with Rhaphidograptus toernquisti and C. cyphus.

\section{Pseudoretiolites cf. perlatus (Nicholson, 1868)}

Several, presumably tectonically widened rhabdosomes closely resembling Pseudoretiolites perlatus are associated with graptolites indicating Pribylograptus leptotheca and Stimulograptus sedgwickii biozones. The rhabdosomes widen rapidly at the proximal end (Fig. 13). The thecae are straight, inclined at $\mathrm{ca} 70^{\circ}$ and barely distinguishable in some specimens. The apertural parts are formed of fine, laterally elongated meshes arranged in a zig-zag pattern. Ellipsoidal retiolitid rhabdosomes from the lowermost Rastrites linnaei Biozone of Thuringia, described as Pseudoretiolites decurtatus by Bouček \& Münch (1944), may be distinguished from Pseudoretiolites perlatus by their dense reticular meshwork and closely spaced thecae.

\section{Stomatograptus imperfectus Bouček \& Münch, 1944}

A single, $77 \mathrm{~mm}$ long rhabdosome widens rapidly from an initial width of $c a 1.9 \mathrm{~mm}$ to $4.8 \mathrm{~mm}$ attained after $c a$ $10 \mathrm{~mm}$. Thereafter the rhabdosome widens very gradually up to the distal maximum of $7.8 \mathrm{~mm}$ (Fig. 10J). Generic assignment is based upon median row of ellipsoidal stomata and the presence of partly sclerotized thecal floors (sensu Lenz \& Melchin 1987). The present specimen is distinguishable from Stomatograptus grandis (Suess) by its less ra- pidly widening rhabdosome, more acute ventral apertural margins and less sclerotized subapertural thecal floors. This specimen was found in association with Cochlograptus veles and Torquigraptus tullbergi, species from well below the known stratigraphic range of Stomatograptus grandis.

\section{Pribylograptus leptotheca (Lapworth, 1876)}

The material consists of straight, 1.4-1.5 mm wide distal parts of very long rhabdosomes (Fig. 9J). The species was determined by its long, straight, very gently inclined, and greatly overlapping thecae.

\section{Pribylograptus cf. spiculiformis (Ni, 1978)}

Three dorsally curved rhabdosomes with straight tubular thecae, straight apertures and ca $1 \mathrm{~mm}$ long, spinose, ventrally directed genicular hoods (Figs 6A, 9D) were found with a triangulatus Biozone assemblage (Coronograptus gregarius, Demirastrites triangulatus, Rastrites longispinus, Monograptus revolutus s.l., Campograptus communis a.o.). Pristiograptid thecae overlapping for more than half their length, combined with long, presumably unpaired genicular spines and dorsally curved rhabdosome strongly resemble Pribylograptus spiculiformis described by $\mathrm{Ni}$ (1978) from the Coronograptus leei Biozone of Western Hubei, China. The early rastritids that accompanied Pribylograptus spiculiformis indicate a stratigraphic level close to the Demirastrites triangulatus Biozone sensu Bouček (1952). The genicular spines of the present specimens are longer and the thecae less, if at all, geniculated than observed in other comparable taxa (huttagraptids, early monoclimacids). Pribylograptus sp. recorded by Loydell et al. (2003) from the lower Demirastrites triangulatus Biozone of Aizpute-41 core in Latvia exhibits dorsally curved rhabdosome and thecae with long spinose genicular hoods. Latvian rhabdosome is apparently more robust than Chinese specimens. Further comparison is biased by modest preservation of the Chinese specimen (personal observation) on one side and missing systematic description of the Latvian material one the other side.

Figure 11. A - Rastrites cf. gracilis Přibyl, 1942 and fragmentary Torquigraptus involutus Lapworth, 1876, S 05081. • B - "Monograptus" revolutus Kurck, 1882, s.1., S 05089. • C - Glyptograptus tamariscus (Nicholson, 1868), S 05082. • D - Campograptus millepeda (McCoy, 1850), S 05083a. - E - Torquigraptus proteus (Barrande, 1850), S 05086. • F - Torquigraptus pragensis (Přibyl, 1943), S 05047. • G - Normalograptus nikolayevi (Obut, 1965), S 05094. • H - Campograptus clingani (Carruthers, 1867), S 05080. •I - Spirograptus turriculatus (Barrande, 1850), S 05046. • J - Demirastrites pectinatus (Richter, 1853), S 05084. • K - Parapetalolithus regius (Hundt, 1957), S 05007. • A-C, E-I, K - Mrákotín, locality 3a: (A) sedgwickii Biozone, (B, G) triangulatus Biozone, (C) leptotheca Biozone, (E) ?turriculatus Biozone, (F) griestoniensis Biozone, (H) convolutus Biozone, (I) turriculatus Biozone and (K) linnaei Biozone; D, J - Mrákotín, locality 1: (D) leptotheca Biozone and (J) pectinatus Biozone. All specimens $\times 4$. White bars show the direction of tectonic elongation. 
Petr Štorch \& Petr Kraft • Graptolite of the lower Silurian Mrákotín Formation, Hlinsko Zone
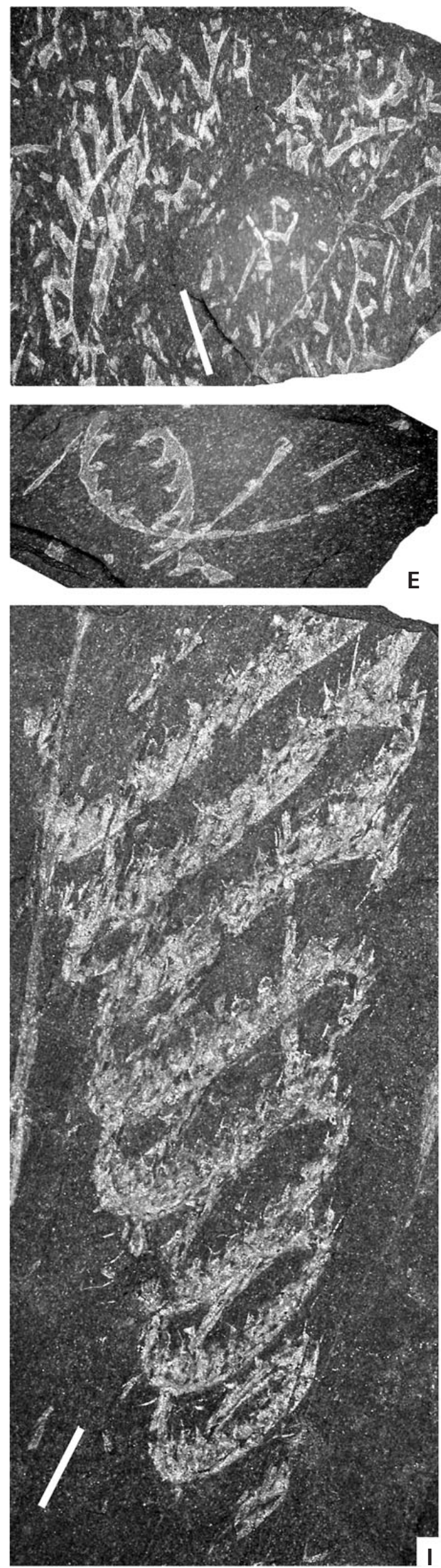
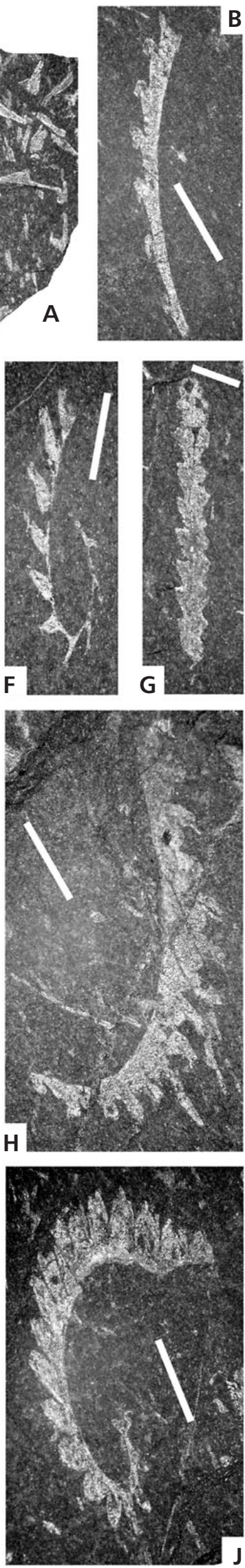
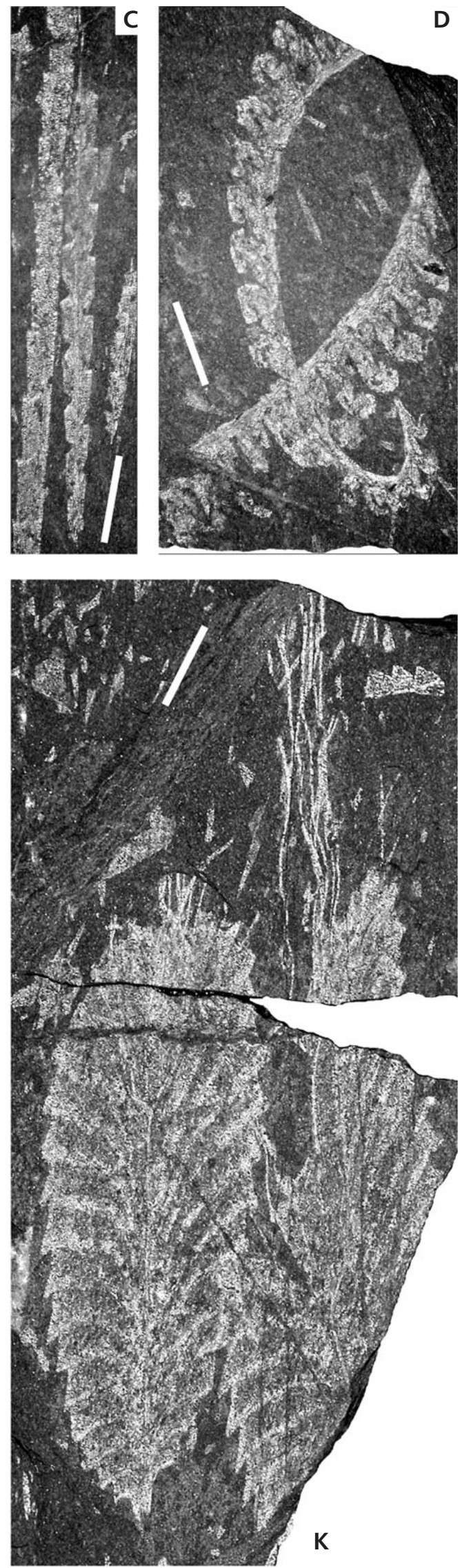


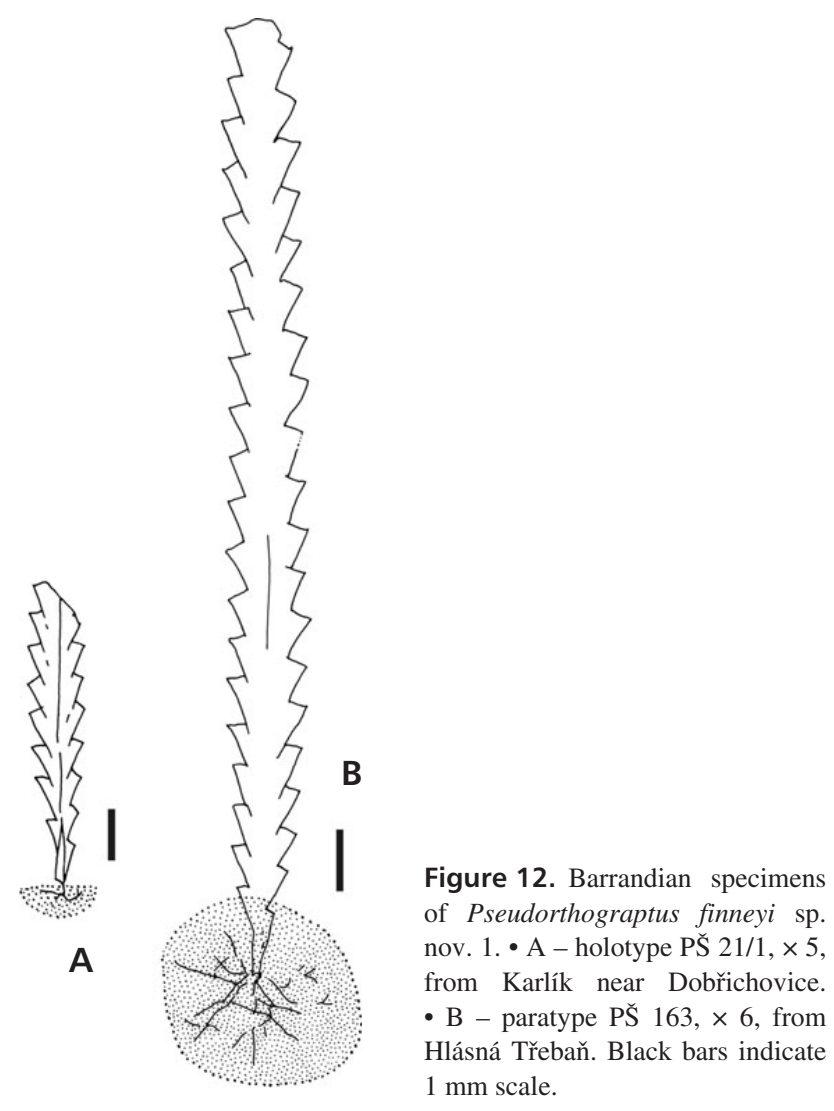

Campograptus clingani (Carruthers, 1867)

This was found in the Lituigraptus convolutus Biozone sample. It is easily distinguishable from other similar dorsally curved monograptids, and campograptids in particular, by its robust proximal end and hooked thecae with broad prothecal base and ventral prothecal wall nearly parallel to the rhabdosome. The latter feature is barely seen in our specimen (Figs 7D, 11H) due to tectonic effects. The proximal-facing thecal apertures are furnished with lateral spines.

\section{Torquigraptus australis Štorch, 1998}

This middle Telychian torquigraptid can be readily distinguished from other middle and late Telychian spiraliform taxa by its relatively slender rhabdosome which is enrolled in a regular planar spiral with a straightened proximal part composed of $c a 6$ axially elongated, long-triangular thecae (Fig. 10A). Mesial and distal thecae with laterally twisted apertures grow perpendicular or sub-perpendicular to the spiral plane. Torquigraptus tullbergi (Bouček, 1931) widens more rapidly in the proximal part, the distal form of the thecae developed earlier in its astogeny and its rhabdosome never forms such a tight and regular planar spiral. Torquigraptus spiraloides (Přibyl, 1944) exhibits more isolated and higher metathecae proximally and a greater dorso-ventral width distally. Its rhabdosome spiral is helical rather than planar.

\section{Torquigraptus pragensis (Přibyl, 1943)}

Twelve specimens were found in several loose blocks in association with other graptolites indicating Monoclimacis griestoniensis Biozone. The species possesses highly triangular isolated thecae with small, laterally facing apertural hooks. The $c a$ seven proximal metathecae are slender, almost rastritiform; the following metathecae become more triangular and less isolated (Figs 6F-H, 10G, 11F). Zalasiewicz (1994) illustrated markedly asymmetrical, and overlapping distal thecae that were not recognized by Pribyl (1943) and Štorch \& Serpagli (1993).

\section{Pseudostreptograptus? aff. loydelli (sensu Zalasiewicz 1994)}

The hook-shaped rhabdosome is similar to Streptograptus loydelli Storch \& Serpagli, 1993 in its shape, dorso-ventral width and thecal spacing. The thecae are furnished, however, with branching spines closely resembling the lateral spatulate processes (Figs 6K, 10F) revealed by Loydell (1991a) in Pseudostreptograptus williamsi (see also Loydell \& Maletz 2004) from the basal Telychian Spirograptus guerichi or Rastrites linnaei biozones. The present specimens are associated with Torquigraptus pragensis, Cochlograptus veles, Monograptus ex gr. priodon and Monoclimacis sp. indicating a considerably higher stratigraphic level, similar to that of Streptograptus loydelli. The present taxon may be identical to Streptograptus aff. loydelli of Zalasiewicz (1994) which occurs in the lower Monoclimacis griestoniensis Biozone and also possesses spinose thecae. Due to its spinose thecae, Streptograptus aff. loydelli sensu Zalasiewicz has been tentatively assigned to Pseudostreptograptus in this paper.

\section{Demirastrites pectinatus (Richter, 1853)}

This species, although tectonically deformed, is well distinguishable from other triangulate monograptids by its isolated but distally tightly appressed metathecae (Figs 7B, 8C, 11J). The earliest 3-4 thecae are highly triangular, separated, almost rastritid in form, the following thecae become robust, rather pectinate in outline, and possibly possess short, widely triangular lateral processes similar to those in Lituigraptus. Demirastrites pectinatus is common in the Hlinsko Zone but rarely found together with Demirastrites triangulatus, hence recognition of two separate biozones. 


\section{Lituigraptus richteri (Perner, 1897)}

Several dorsally coiled rhabdosomes with rastritid proximal and mesial thecae belong to Lituigraptus richteri - a characteristic element of the Pribylograptus leptotheca Biozone assemblage. The thecal spacing and height of the metathecae are typical of this species. The triangular lateral processes (Fig. 6I) on sub-proximal thecae suggest a distinct morphological transition to Lituigraptus convolutus.

\section{Lituigraptus convolutus (Hisinger, 1837)}

Common fragmentary rhabdosomes of Lituigraptus convolutus are readily distinguishable from other rastritiform species by the prominent, paired, ventrally or proximo-ventrally directed lateral apertural processes (Fig. 9A, I).

\section{Systematic palaeontology}

Family Petalolithidae Bulman, 1955, emend. Melchin, 1998

\section{Genus Pseudorthograptus Legrand, 1987}

Type species. - Diplograptus insectiformis Nicholson, 1869.

\section{Pseudorthograptus finneyi sp. nov.} Figures 6N, O, 12A, B

?1975 Orthograptus cyperoides (Törnquist, 1897). - Bjerreskov, pp. 28, 29, text-fig. 10D.

1985 Orthograptus cyperoides Törnquist, 1897. - Štorch, p. 90, pl. 1, figs 1-4, text-fig. $2 \mathrm{~F}, \mathrm{G}$.

?1991b “Orthograptus" cyperoides (Törnquist, 1897). - Loydell, p. 678, pl. 1, figs 10-15.

Holotype. - Specimen No. PŠ 21/1 figured by Štorch (1985) on Pl. 1, fig. 5 and text-fig. 2G; refigured herein on Fig. 12A; from the lowermost Demirastrites triangulatus-Demirastrites pectinatus Biozone at Karlík near Dobřichovice, Bohemia.

Material. - 25 flattened, mostly complete specimens from the Barrandian area, seven tectonically deformed flattened rhabdosomes from the Hlinsko Zone.

Diagnosis. - Small pseudorthograptid with wedge-shaped proximal part and parallel-sided distal part. Maximum width of $1.2 \mathrm{~mm}$ attained by the $c a 6^{\text {th }}$ theca. The sicula is ca $1.7 \mathrm{~mm}$ long, exposed for $0.6-0.8 \mathrm{~mm}$ on dorsal side below th $1^{2}$. The virgella is divided almost immediately into a

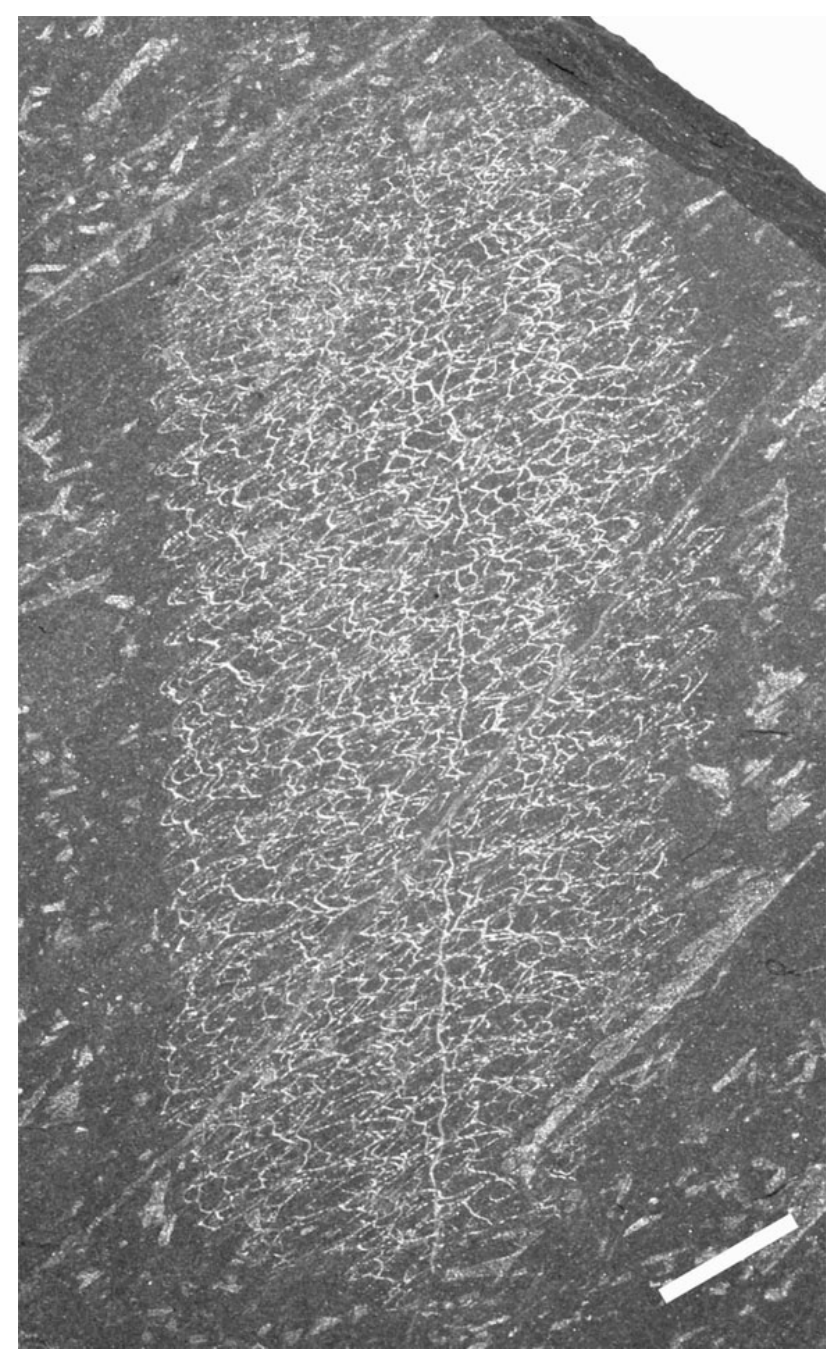

Figure 13. Pseudoretiolites cf. perlatus (Nicholson, 1868), S 05044a, x 4; sedgwickii Biozone, Mrákotín, locality $3 \mathrm{a}$.

complex, dish-shaped ancora, often covered by a membranous tissue. Thecae are simple tubes, inclined at $20-30^{\circ}$, numbering 7 in $5 \mathrm{~mm}$; straight thecal apertures are perpendicular to thecal axis.

Discussion. - Pseudorthograptus finneyi was described in detail by Štorch (1985) and refered to Orthograptus cyperoides Törnquist, 1897. The latter species, however, is less tapering proximally and doesn't possess the complex ancora. Its type material originates from the Cephalograptus cometa (i.e. Lituigraptus convolutus) Biozone of Tommarp, Sweden. Rickards \& Koren' (1996) assigned Orthograptus cyperoides to Rivagraptus and excluded the ancorate specimens figured by Štorch (1985) and Loydell (1991b) from Törnquist's (1897) taxon. Indeed, the only specimen figured by Rickards \& Koren' (1996, text-fig. 12E) is from Coronograptus gregarius Biozone and differs from the Barrandian form also in its less pro- 
tracted proximal end and less delayed th $\mathrm{l}^{2}$. A specimen from the upper Coronograptus gregarius Biozone of Bornholm, figured by Bjerreskov (1975, text-fig. 10D), differs from that of Loydell (1991b) only in having very thin apertural spines and ancora-like structure proximally. The taxonomic identity of the latter two specimens is uncertain. Specimens assigned to O. cyperoides by Hutt (1974) can be distinguished from $P$ s. finneyi by their less protracted proximal part, without ancora, less delayed th $1^{2}$, and thecal tubes inclined at a higher angle. Both Pseudorthograptus insectiformis (Nicholson, 1869) and Pseudorthograptus inopinatus (Bouček, 1944) may be readily distinguished from Pseudorthograptus finneyi sp. nov. by their prominent thecal apertural spines, which are regularly preserved in both Barrandian and Hlinsko material. The former two species have less protracted and less asymmetrical proximal ends and little exposure of the sicula.

Pseudorthograptus finneyi occurs in the uppermost $C o$ ronograptus cyphus and lower Demirastrites triangulatus-Demirastrites pectinatus biozones in the Barrandian area, it is fairly common in the C. cyphus-Dem. triangulatus boundary beds whereas records from the "Monograptus" simulans Biozone are doubtful although the specimen figured by Loydell (1991b) came from the stratigraphically almost equivalent "Monograptus" argenteus Biozone. Pseudorthograptus finneyi is a common element of the Dem. triangulatus Biozone assemblage also in the Hlinsko area. Some specimens illustrate an extreme degree of tectonic deformation (Fig. 6N).

\section{Conclusions}

The majority of graptolite biozones, so far recognized in the Llandovery succession of the classical Barrandian area of central Bohemia, has been identified in the Hlinsko Zone (Tabs 1, 2 and Fig. 5). The Rhuddanian Cystograptus vesiculosus and Coronograptus cyphus biozones, Aeronian Demirastrites triangulatus, Demirastrites pectinatus, ?"Monograptus" simulans, Pribylograptus leptotheca, Lituigraptus convolutus and Stimulograptus sedgwickii biozones and Telychian Rastrites linnaei, Spirograptus turriculatus, Streptograptus crispus, Monoclimacis griestoniensis, Torquigraptus tullbergi and Oktavites spiralis biozones were identified in loose boulders, the late Telychian Torquigraptus tullbergi and Oktavites spiralis zones were found in outcrop, in the abandoned Picek's Quarry (Tab. 1).

No Wenlock taxa occur among the 112 graptolite species that we have recorded in the black-shale succession of the Hlinsko Zone (Tab. 2).

There is no striking difference between the graptolite fauna of the Hlinsko area and that of the Barrandian area. The lithological successions of the two areas, however, differ. Barren greenish mudstone beds which, in the Barrandian area, intercalate with black graptolitic shales of the upper Llandovery Litohlavy Formation are missing in the Hlinsko Zone (Fig. 5). The whole Llandovery succession - Mrákotín Formation - of the Hlinsko Zone is composed of black slates and silicites in the lower part whilst the rocks became less siliceous in the upper Llandovery, in the Torquigraptus tullbergi and Oktavites spiralis biozones in particular. Light coloured flat nodules and thin lenticular intercalations are common in this formation and closely resemble the phosphatic nodules typical of Saxo-Thuringian facies of the Silurian (Jaeger 1976). Thus the Llandovery sediments of the Mrákotín Formation may have been deposited far from the depositional sites of the coeval rocks of the Barrandian area, apparently in less oxic, more offshore depositional settings similar to those of the Silurian black shales of SaxoThuringia, Bardo Mts of West Sudetes and Sardinia.

\section{Acknowledgement}

This research was supported financially by the Grant Agency of Academy of Sciences of the Czech Republic, project No. IAA3013406. Petr Kraft was also supported by project MSM0021620855 of the Ministry of Education, Youth and Sport of the Czech Republic, Petr Štorch's study participated on research plan CEZ: Z3 013912 carried out by the Institute of Geology AS CR, Prague. We are indebted to Jaroslava Pavková for preparing figure 5. Graptolites were photographed in collaboration with Josef Brožek. Štěpán Manda and David Loydell are thanked for their helpful comments on the earlier version of the manuscript. This paper is a contribution of the IGCP Project No. 497: "The Rheic Ocean".

\section{References}

BARCA, S. \& JAEGER, H. 1990. New geological and biostratigraphical data on the Silurian in SE-Sardinia. Close affinity with Thuringia. Bolletino della Società geologica italiana 108(1989), 565-580.

BARRANDE, J. 1850. Graptolites de Bohême. 74 pp, 4 pls. Published by the author, Prague.

BJERRESKOV, M. 1975. Llandoverian and Wenlockian graptolites from Bornholm. Fossils and Strata 8, 1-94.

BOUČEK, B. 1931. Předběžná zpráva o některých nových druzích graptolitů v českém Gothlandienu. Věstník Státního geologického ústavu 7, 293-313.

BOUČEK, B. 1944. O některých ostnitých diplograptidech českého a saského siluru. Rozpravy České akademie věd a umění, Tř́da 2, 53(25), 1-6.

BOUČEK, B. 1953. Biostratigraphy, Development and Correlation of the Želkovice and Motol Beds of the Silurian of Bohemia. Sborník Ústředního Ústavu geologického, Oddíl paleontologický 20, 421-484.

BOUČEK, B. \& MÜNCH, A. 1944. Die Retioliten des mitteleuro- 
paischen Llandovery und unteren Wenlock. Rozpravy České akademie věd a umění, Tř́lda 2, 53(41), 1-54.

BOUČEK, B. \& PřIBYL, A. 1941. O Petalolithech ze skupiny $P$. folium (His.) a o rodu Cephalograptus Hopk. Rozpravy České akademie věd a umění, Tř́da 2, 51(26), 1-23.

Bulman, O.M.B. 1955. Graptolithina. In MoORE, R.C. (ed.) Treatise on invertebrate paleontology. Part V. Geological Society of America \& University of Kansas Press, New York \& Lawrence.

CARRUTHERS, W. 1867. Graptolites: their structure and systematic position. Intellectual Observer 11(4), 283-292, 365-374.

ChÁB, J., Breiter, K., FATKa, O., Hladil, J., Kalvoda, J., ŠIMŮNEK, Z., ŠTORCH, P. VAŠíčEK, Z., ZAJíC, J. \& ZAPLETAL, J. 2008. Stručná geologie základu Českého masivu a jeho karbonského a permského pokryvu. 283 pp. Česká geologická služba, Praha.

ChlupáČ, I., BrZObohatý, R., Kovanda, J. \& StrÁníK, Z. 2002. Geologická minulost české republiky. 436 pp. Academia, Praha.

ChURKIn, M. \& CARTER, C. 1970. Early Silurian graptolites from southeastern Alaska and their correlation with graptolitic sequences in North America and the Arctic. United States Geological Survey Professional Paper 653,1-51.

ElLES, G.L. \& WoOD, E.M.R. 1906. A monograph of British graptolites. Monograph of the Palaeontographical Society, Part 5, 181-216.

ELLES, G.L. \& WoOD, E.M.R. 1908. A monograph of British graptolites. Monograph of the Palaeontographical Society, Part 7, 273-358.

ELLES, G.L. \& WoOD, E.M.R. 1913. A monograph of British graptolites. Monograph of the Palaeontographical Society, Part 9, 415-486.

GEINITZ, H.B. 1842. Über die Graptolithen. Neues Jahrbuch für Mineralogie, Geografie, Geologie und Petrefakten-Kunde, 697-701.

GuTTIÉRREZ-MARCO, J.C. \& ŠTORCH, P. 1998. Graptolite biostratigraphy of the Lower Silurian (Llandovery) shelf deposits of the Western Iberian Cordillera, Spain. Geological Magazine 135, 71-92. DOI 10.1017/S0016756897007802

HARKNESS, R. 1851. Description of the Graptolites found in the Black Shales of Dumfriesshire. Quarterly Journal of the Geological Society of London 7, 58-65.

Hisinger, H. 1837. Lethaea Suecica seu Petrifacta Suecica, Supplementum 1. 124 pp, 2 pls. Stockholm.

HORNÝ, R. 1956. Nové poznatky o biostratigrafii skutečsko-hlinského siluru. Věstník Ústředního ústavu geologického 31, 128-131.

HunDT, R. 1957. Schwebeblasen bei Graptolithen (Diplograptidae) ein Beitrag zu ihrer Lebensweise. 200 Jahre Naturkundesmuseum. Heidecksburg, 79-95.

HUTT, M. 1974. The Llandovery graptolites of the English Lake District, Part 1. Monograph of the Palaeontographical Society 128(540), 1-56.

HuTT, M. 1975. The Llandovery graptolites of the English Lake District, Part 2. Monograph of the Palaeontographical Society 129(542), 57-137.
JAEGER, H. 1976. Das Silur und Unterdevon vom thüringischen Typ in Sardinien und seine regionalgeologische Bedeutung. Nova Acta Leopoldina, N.F., 224(45), 263-299.

KIRSTE, E. 1919. Die Graptolithen des Altenburger Ostkreises. Mitteilungen Osterlände 16, 60-222.

KonZALOVÁ, M. \& VACHTL, J. 1976. On age of the Rychmburk Greywacke. Věstník Ústředního ústavu geologického 51(3), 129-138.

KREMER, B. 2005. Mazuelloids: product of post-mortem phosphatization of acanthomorphic acritarchs. Palaios 20, 27-36. DOI 10.2110/palo.2003.p03-112

KREMER, B. \& KAŹMIERCZAK, J. 2005. Cyanobacterial mats from Silurian black radiolarian cherts: phototrophic life at the edge of darkness? Journal of Sedimentary Research 75, 897-906. DOI 10.2110/jsr.2005.069

KURCK, C. 1882. Några nya graptolitarter från Skåne. Geologiska Föreningens i Stockholm Förhandlingar 6, 294-304.

LAPWORTH, C. 1876. On Scottish Monograptidae. Geological Magazine 3(2), 308-321, 350-360, 499-507, 544-552.

LAPWORTH, C. 1877. Graptolites of County Down. Proceedings of the Belfast Naturalists Field Club, Appendix 1876-77, 125-144.

LEGRAND, P. 1987. Modo de desarrollo del suborden Diplograptina (Graptolithina) en el Ordovícico superior y en el Silúrico. Implicaciones taxonómicas. Revista Española de Paleontologia 2, 59-64.

LENZ, A.C. \& MELCHIN, M.J. 1987. Peridermal and interthecal tissue in Silurian retiolitid graptolites: with examples from Sweden and Arctic Canada. Lethaia 20, 353-359. DOI 10.1111/j.1502-3931.1987.tb00795.x

LOYDELL, D.K. 1991a. The biostratigraphy and formational relationships of the Upper Aeronian and lower Telychian (Llandovery, Silurian) formations of western mid-Wales. Geological Journal 26, 209-244. DOI $10.1002 / \mathrm{gj} .3350260304$

LOYDELL, D.K. 1991b. Isolated graptolites from the Llandovery of Kallholen, Sweden. Palaeontology 34, 671-693.

LOYDELL, D.K. 1992. Upper Aeronian and lower Telychian (Llandovery) graptolites from western mid-Wales, Part 1. Monograph of the Palaeontographical Society 147(589), $1-55$.

LOYDELL, D.K. \& MALETZ, J. 2004. The Silurian graptolite genera Streptograptus and Pseudostreptograptus. Journal of Systematic Palaeontology 2(2), 65-93.

DOI $10.1017 /$ S1477201904001117

LOYDELl, D.K., MÄNNIK, P. \& NeSTOR, V. 2003. Integrated biostratigraphy of the lower Silurian of the Aizpute-41 core, Latvia. Geological Magazine 140(2), 205-229.

DOI $10.1017 / \mathrm{S} 0016756802007264$

LOYDELL, D.K., S̆TORCH, P. \& MELCHIN, M.J. 1993. Taxonomy, evolution and biostratigraphical importance of the Llandovery graptolite Spirograptus. Palaeontology 36(4), 909-926.

MALINOWSKA, L. 1955. Stratygrafia Gotlandu Gor Bardzkich. Biuletyn Instytutu Geologicznego 95, 5-88.

MCCOY, F. 1850. On some new genera and species of Silurian Radiata in the collection of the University of Cambridge. Annals and Magazine of Natural History 6(2), 270-290. 
MELCHIN, M.J. 1998. Morphology and phylogeny of some early Silurian 'diplograptid' genera from Cornwallis Island, Arctic Canada. Palaeontology 41, 263-315.

MELCHIN, M.J., KOREN', T.N. \& ŠTORCH, P. 1998. Global diversity and survivorship patterns of Silurian graptoloids, 165-182. In LANDING, E. \& JoHnson, M.E. (eds) Silurian Cycles: linkages of dynamic processes in the atmosphere and oceans. New York State Museum Bulletin 491.

Ni YU-NAN, 1978. Lower Silurian graptolites from Yichang, Western Hubei. Acta Palaeontologica Sinica 17, 387-420.

NiCHOLSON, H.A. 1868. On the graptolites of the Coniston Flags; with notes on the British species of the genus Graptolites. Quarterly Journal of the Geological Society of London 24, 521-545.

NiCHOLSON, H.A. 1869. On some new species of graptolites. Annals and Magazine of Natural History 4, 231-242.

OBUT, A.M. 1965. Graptolity silura Omulevskich gor (Bassein reky Kolymy), 33-46. In Stratigrafia $i$ Paleontologia Asiatskoy chasti USSR. Nauka, Moskva.

PERNER, J. 1897. Études sur les Graptolites de Bohême. III ième Partie. Monographie des Graptolites de l'Étage E, Section a. 25 pp. Gerhard, Prague.

PitrA, P., Burg, J.-P., SchulmanN, K. \& LedRU, P. 1994. Late orogenetic extension in the Bohemian Massif: petrostructural evidence in the Hlinsko region. Geodinamica Acta 7(1), 15-30.

PŘIBYL, A. 1942. Příspěvek k poznání německých zástupců rodu Rastrites. Rozpravy České akademie věd a umění, Třída 2, 52(4), 1-11.

PřIBYL, A. 1943. Einige neue Graptolithen aus dem böhmischen und deutschen Silur. Věstník Královské České společnosti nauk, Tř́ida matematicko-přirodovědná (1943), 1-26.

PŘIBYL, A. 1944. O středoevropských monograptech z rodu Spirograptus Gürich. Rozpravy České akademie věd a umění, Třída 2, 54(19), 1-46.

RICHTER, R. 1853. Thüringische Graptolithen. Zeitschrift der Deutschen Geologischen Gesellschaft 5, 439-464.

Richter, R. 1871. Aus dem Thüringischen Schiefergebirge. Zeitschrift der Deutschen Geologischen Gesellschaft 23, 231-256.

RICKARDS, R.B. 1970. The Llandovery (Silurian) graptolites of the Howgill Fells, Northern England. Monograph of the Palaeontographical Society 123(524), 1-108.
RICKARDS, R.B. \& KOREN', T.N. 1974. Virgellar meshworks and sicular spinosity in Llandovery graptoloids. Geological Magazine 111, 193-204.

RICKARDS, R.B. \& KOREN', T.N. 1996. Taxonomy and evolution of Llandovery biserial graptoloids from the southern Urals, western Kazakhstan. Special Papers in Palaeontology 54, 1-103.

SCHAUER, M. 1971. Biostratigraphie und Taxionomie der Graptolithen des tieferen Silurs unter besonderer Berücksichtigung der tektonischen Deformation. Freiberger Forschungshefte, Reihe C 373, 1-185.

ŠTORCH, P. 1985. Orthograptus s.l. and Cystograptus (Graptolithina) from the Bohemian lower Silurian. Věstník Ústředního ústavu geologického 60, 87-99.

S̆TORCH, P. 1994. Graptolite biostratigraphy of the Lower Silurian (Llandovery and Wenlock) of Bohemia. Geological Journal 29, 137-165.

ŠTORCH, P. 1998. New data on Telychian (Upper Llandovery, Silurian) graptolites from Spain. Journal of the Czech Geological Society 43(3), 113-141.

S̆TORCH, P. 2006. Facies development, depositional settings and sequence stratigraphy across the Ordovician-Silurian boundary: a new perspective from the Barrandian area of the Czech Republic. Geological Journal 41, 163-192. DOI $10.1002 / \mathrm{gj} .1038$

ŠTORCH, P. \& SERPAGLI, E. 1993. Lower Silurian graptolites from Southwestern Sardinia. Bolletino della Società Paleontologica Italiana 32(1), 3-57.

TÖRNQUIST, S.L. 1890. Undersokningar öfver Siljansområdets graptoliter. Pt. 1. Lunds Universitets Arsskrifter 26, 1-33.

TÖRNQUIST, S.L. 1897. On the Diplograptidae and Heteroprionidae of the Scanian Rastrites beds. Lunds Universitets Arsskrifter 33, 1-24.

WURM, A. 1927. Stárí buližníků v okolí Hlinska. Věstník Státního geologického ústavu Československé republiky 3, 169-172.

ZALASIEWICZ, J. 1990. Silurian graptolite biostratigraphy in the Welsh Basin. Journal of the Geological Society, London 147, 619-623. DOI 10.1144/gsjgs.147.4.0619

ZALASIEWICZ, J. 1994. Middle to late Telychian (Silurian, Llandovery) graptolite assemblages of central Wales. Palaeontology 37(2), 375-396.

ZALASIEWICZ, J. 1996. Aeronian (Silurian: Llandovery) graptolites from central Wales. Geologica et Palaeontologica 30, 1-14. 